\title{
Global Distribution of Babesia Species in Questing Ticks: A Systematic Review and Meta-Analysis Based on Published Literature
}

\author{
ThankGod E. Onyiche ${ }^{1,2}{ }^{(}$, Cristian Răileanu ${ }^{2}\left(\mathbb{D}\right.$, Susanne Fischer ${ }^{2}$ and Cornelia Silaghi ${ }^{2,3, *}$ \\ 1 Department of Veterinary Parasitology and Entomology, University of Maiduguri, P. M. B. 1069, \\ Maiduguri 600230, Nigeria; et.onyiche@unimaid.edu.ng \\ 2 Institute of Infectology, Friedrich-Loeffler-Institut, Federal Research Institute for Animal Health, Südufer 10, \\ 17493 Greifswald-Insel Riems, Germany; cristian.raileanu@fli.de (C.R.); susanne.fischer@fli.de (S.F.) \\ 3 Department of Biology, University of Greifswald, Domstrasse 11, 17489 Greifswald, Germany \\ * Correspondence: cornelia.silaghi@fli.de; Tel.: +49-38351-7-1172
}

Citation: Onyiche, T.E.; Răileanu, C.; Fischer, S.; Silaghi, C. Global

Distribution of Babesia Species in

Questing Ticks: A Systematic Review and Meta-Analysis Based on

Published Literature. Pathogens 2021,

10, 230. https://doi.org/10.3390/

pathogens 10020230

Academic Editor:

Vyacheslav Yurchenko

Received: 20 January 2021

Accepted: 17 February 2021

Published: 19 February 2021

Publisher's Note: MDPI stays neutral with regard to jurisdictional claims in published maps and institutional affiliations.

Copyright: (ㄷ 2021 by the authors. Licensee MDPI, Basel, Switzerland. This article is an open access article distributed under the terms and conditions of the Creative Commons Attribution (CC BY) license (https:// creativecommons.org/licenses/by/ $4.0 /)$.

\begin{abstract}
Babesiosis caused by the Babesia species is a parasitic tick-borne disease. It threatens many mammalian species and is transmitted through infected ixodid ticks. To date, the global occurrence and distribution are poorly understood in questing ticks. Therefore, we performed a meta-analysis to estimate the distribution of the pathogen. A deep search for four electronic databases of the published literature investigating the prevalence of Babesia spp. in questing ticks was undertaken and obtained data analyzed. Our results indicate that in 104 eligible studies dating from 1985 to 2020, altogether 137,364 ticks were screened with 3069 positives with an estimated global pooled prevalence estimates (PPE) of $2.10 \%$. In total, 19 different Babesia species of both human and veterinary importance were detected in 23 tick species, with Babesia microti and Ixodes ricinus being the most widely reported Babesia and tick species, respectively. Regardless of species, adult ticks with $2.60 \%$ had the highest infection rates, while larvae had the least with $0.60 \%$. Similarly, female ticks with $4.90 \%$ were infected compared to males with $3.80 \%$. Nested-polymerase chain reaction (PCR) $2.80 \%$ had the highest prevalence among the molecular techniques employed. In conclusion, results obtained indicate that Babesia species are present in diverse questing tick species at a low prevalence, of which some are competent vectors.
\end{abstract}

Keywords: Babesia; questing tick; global; prevalence; molecular; meta-analysis

\section{Introduction}

Both Theileria and Babesia species belong to the order Piroplasmida, are widely distributed and are among the economically important tick-borne hemoparasites of mammals [1]. Babesiosis has been well-known since the 19th century and is distributed worldwide as a disease of veterinary importance in cattle, sheep, pigs, dogs, and horses and in recent times has attracted attention as a zoonotic infection in humans [2,3].

Babesia is second only after Trypanosomes globally as the commonly found hemoparasites in the blood of mammals [4]. In 1888, Victor Babes, a Romanian biologist, was the first to discover the presence of intra-erythrocytic microorganisms in the blood of cattle, and he later observed similar intra-erythrocytic organisms in the blood of sheep [5]. A few years later, these microorganisms, which were later named "Babesia", were noted in the blood of cattle in the United States [6]. These microorganisms in cattle were named Babesia bovis and B. bigemina, and in sheep, B. ovis [7]. Ever since, different species of Babesia have been observed parasitizing the blood of domestic animals. Over 100 species have been described thanks to the advances in microscopy, cell culture, and molecular techniques [1,3]. The clinical manifestations of babesiosis vary considerably across different animal species, but abortions, decreased milk and meat production, and mortality have been observed [8]. 
Furthermore, human babesiosis was first documented in the former Yugoslavia republic in 1957 [9]. Babesiosis in humans is becoming a public health concern as several species, including B. microti, B. divergens and B. venatorum, can infect humans accidentally, causing disease [8]. Babesia microti infections are less acute compared with B. divergens, while those due to $B$. venatorum are milder [10]. Affected persons are often asymptomatic except in immunocompromised individuals where the outcome can be fatal $[8,11]$. Clinical complications, such as hemolysis, acute respiratory distress and multiorgan malfunctioning leading to death have been observed [12].

Ixodid ticks are obligate hematophagous acarines, which feed on a wide variety of hosts, and over 700 species have been described [13]. To complete their life cycle, ticks must look for suitable hosts. Therefore, newly hatched larvae, nymphs and adults that are unfed need to seek a host for a blood meal for their further development into the next stage [14]. Detection and attachment to potential hosts in Ixodidae can be achieved through three major behavioral patterns: hunting, tick-host cohabitation, and questing [15].

Species of questing ticks within the genera Ixodes, Dermacentor and Haemaphysalis have been described and collected for the detection of tick-borne pathogens. Other species within the genus Rhipicephalus and Hyalomma have also been collected from the environment [16]. Questing ticks can be collected principally by flagging or dragging, among other methods, including trapping using baits (e.g., carbon dioxide) [14]. Ixodid ticks are the primary vectors of Babesia, but the parasites are sustained in a complex system of animal reservoirs and tick vectors $[17,18]$. In Ixodid ticks, the sexual phase of the life cycle of Babesia typically takes place acquiring and transmitting the parasites during blood meals from their host $[19,20]$. Transovarial transmission is exclusive within the Babesia sensu stricto evolutionary lineage, thereby allowing the pathogens to perpetuate their long-term persistence in ticks and serving as parasite reservoirs when vertebrate hosts are absent $[18,20]$.

Ixodes ricinus is the most common tick, widely distributed in Europe (Western Palearctic), while the focal distribution of Dermacentor reticulatus has been observed [17,21-25]. Other species like I. scapularis are common in the United States of America [26,27], I. ovatus and Hemaphysalis longicornis in East Asia [28-30] and I. persulcatus in Europe (Russia) and parts of Central and Northern Asia [31,32]. Other species of Rhipicephalid ticks have also been reported globally $[8,33,34]$.

Major interest in the role of questing ticks as vectors of pathogens of zoonotic importance began to emerge in the early 2000s. In questing ticks, aside from B. microti, which has been well reported in Europe, Asia, and America with varying infection rates [35-38], $B$. divergens and $B$. venatorum have been exclusively reported in Europe in the last two decades $[17,39,40]$. Other species of Babesia that infect domestic animals and that have been detected in questing ticks include B. canis [24,41], B. odocoilei [26,42], B. ovata [29,43], B. bigemina $[8,43]$, B. bovis $[43,44]$, B. caballi $[41,45]$, B. capreoli $[17,46,47]$ and many more.

In the last two decades, several individual studies around the world attempted to screen for the presence of Babesia species in questing ticks using molecular techniques, but no attempt has been made to synchronize the results from all these studies. Assessing the global state of the pathogen prevalence in unfed host-seeking ticks is essential to develop effective control measures. Therefore, in this study, we undertook a comprehensive assessment to determine the occurrence of Babesia species in unfed host-seeking ticks collected from vegetation while using globally published epidemiological data. To achieve the above aim, we evaluated prevalence rates according to tick species, region of sampling, life stages of ticks, sex of adult ticks, sampling years and molecular detection techniques.

\section{Results}

\subsection{Literature Search and Eligible Studies}

A total of 4359 relevant articles were identified following a search for all four databases using the procedure enumerated in Figure 1. After the removal of duplicates, we were left with 2826 studies for further review. A careful review of the titles and abstracts was 
done, and a total of 122 full-text articles were downloaded for detailed review. In total, 18 studies were excluded for various reasons. These included (i) the exact number of positive Babesia isolates were not clearly stated $(n=5)$, (ii) non-separation of the number of positive isolates of Babesia from questing ticks and other vertebrate hosts/feeding ticks $(n=4)$, (iii) incomplete information on tick collections $(n=3)$, (iv) lack of delineation of the results of positive Babesia species from other piroplasms $(n=2)$, and (v) no information on the number of tick DNA used for polymerase chain reaction (PCR) screening $(n=2)$, (vi) study with samples size below $40(n=2)$. One hundred and four (104) studies were further subjected to the quantitative synthesis. The quality assessment score (QAS) from the Joanna Briggs Institute (JBI) critical appraisal ranges from 6 to 8 out of a possible score of 9, equivalent to $66.7-88.89 \%$ in 100 out of the 104 included studies. Only 4 studies had a score of 5 (55.67\%) (Table 1; Supplementary Table S2).

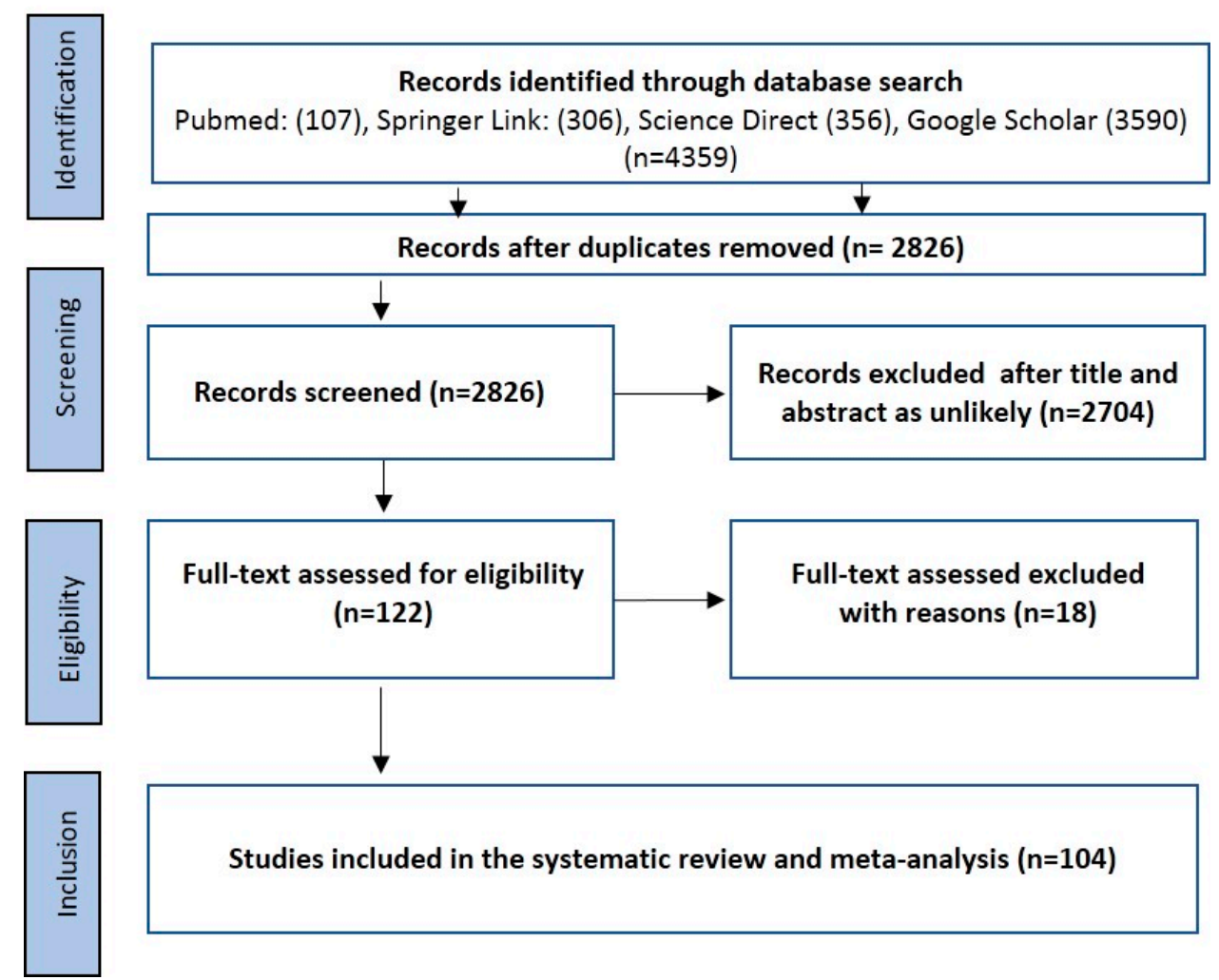

Figure 1. Preferred reporting items for systematic reviews and meta-analyses (PRISMA) flowchart used in the selection of eligible studies.

Table 1. Characteristics of all 104 studies used in the meta-analysis of molecular Babesia detection in questing ticks.

\begin{tabular}{ccccccccc}
\hline Study Year & Country & Continent & $\begin{array}{c}\text { Molecular } \\
\text { Technique }\end{array}$ & $\begin{array}{c}\text { Sample } \\
\text { Size }\end{array}$ & Cases & MIR & JBI QAS & Study Ref. \\
\hline 2005 & Austria & Europe & PCR & 864 & 441 & 51.04 & 5 & {$[2]$} \\
2009 & Belarus & Europe & PCR & 453 & 5 & 1.10 & 7 & {$[48]$} \\
$2016-2017$ & Denmark & Europe & qPCR & 1013 & 5 & 0.49 & 7 & {$[49]$} \\
2015 & Finland & Europe & qPCR/PCR & 515 & 6 & 1.17 & 7 & {$[50]$} \\
$2012-2017$ & Finland & Europe & qPCR & 7070 & 41 & 0.58 & 8 & {$[51]$} \\
2009 & France & Europe & PCR/RLB & 495 & 4 & 0.81 & 7 & {$[52]$} \\
$2006-2007$ & France & Europe & PCR & 572 & 35 & 6.12 & 8 & {$[53]$} \\
2002 & France & Europe & PCR & 92 & 19 & 20.65 & 8 & {$[54]$} \\
$2012-2013$ & France & Europe & PCR & 2620 & 15 & 0.57 & 8 & {$[55]$} \\
2017 & France & Europe & qPCR & 60 & 8 & 13.33 & 8 & {$[56]$} \\
\hline
\end{tabular}


Table 1. Cont.

\begin{tabular}{|c|c|c|c|c|c|c|c|c|}
\hline Study Year & Country & Continent & $\begin{array}{l}\text { Molecular } \\
\text { Technique }\end{array}$ & $\begin{array}{l}\text { Sample } \\
\text { Size }\end{array}$ & Cases & MIR & JBI QAS & Study Ref. \\
\hline 2008 & France & Europe & PCR & 558 & 6 & 1.08 & 8 & [40] \\
\hline 2009 & Germany & Europe & PCR & 226 & 8 & 3.54 & 8 & [57] \\
\hline 2007 & Germany & Europe & PCR & 196 & 21 & 10.71 & 8 & [36] \\
\hline 2008 & Germany & Europe & PCR & 293 & 26 & 8.87 & 8 & [58] \\
\hline 1999-2001 & Germany & Europe & PCR & 3113 & 31 & 0.99 & 8 & [59] \\
\hline $2006-2007$ & Germany & Europe & PCR & 1000 & 50 & 5.00 & 8 & [60] \\
\hline 2006 & Germany & Europe & PCR & 196 & 21 & 10.71 & 8 & [61] \\
\hline 2011-2012 & Germany & Europe & PCR & 4381 & 45 & 1.03 & 8 & [46] \\
\hline 2011 & Germany & Europe & PCR & 199 & 6 & 3.02 & 8 & [38] \\
\hline 2009-2010 & Germany & Europe & PCR & 6593 & 28 & 0.42 & 8 & [47] \\
\hline $2008-2010$ & Germany & Europe & PCR & 1721 & 36 & 2.09 & 8 & [17] \\
\hline 2010-2013 & Germany & Europe & PCR & 339 & 1 & 0.29 & 8 & [24] \\
\hline 2011-2012 & $\begin{array}{l}\text { Germany } \\
\text { Germany, }\end{array}$ & Europe & PCR & 2000 & 0 & 0 & 8 & [62] \\
\hline * 2010-2018 & $\begin{array}{l}\text { Netherland, } \\
\text { Belgium, and } \\
\text { Great Britain }\end{array}$ & Europe & $\begin{array}{l}\text { Microfluidic } \\
\text { qPCR }\end{array}$ & 1486 & 16 & 1.08 & 6 & [25] \\
\hline 2006-2008 & Hungary & Europe & PCR & 1800 & 15 & 0.83 & 5 & [63] \\
\hline 2014-2015 & Hungary & Europe & PCR & 413 & 34 & 8.23 & 8 & [21] \\
\hline 2006-2008 & Italy & Europe & PCR & 191 & 1 & 0.52 & 8 & [64] \\
\hline 2006 & Italy & Europe & PCR & 356 & 3 & 0.84 & 6 & [65] \\
\hline 2006-2007 & Italy & Europe & $\begin{array}{l}\text { Nested } \\
\text { PCR }\end{array}$ & 1861 & 19 & 1.02 & 7 & [66] \\
\hline 2000-2001 & Italy & Europe & $\begin{array}{l}\text { Multiplex } \\
\text { PCR }\end{array}$ & 1931 & 31 & 1.61 & 5 & {$[67]$} \\
\hline 2005-2007 & Latvia & Europe & PCR & 1125 & 19 & 1.69 & 8 & [68] \\
\hline 2006 & $\begin{array}{l}\text { Latvia and } \\
\text { Lithuania }\end{array}$ & Europe & $\begin{array}{l}\text { Nested } \\
\text { PCR }\end{array}$ & 2810 & 40 & 1.42 & 8 & [69] \\
\hline 2006-2008 & Norway & Europe & $\begin{array}{c}\text { qPCR, } \\
\text { nested PCR }\end{array}$ & 1908 & 17 & 0.89 & 8 & [70] \\
\hline 2006 & $\begin{array}{l}\text { Norway and } \\
\text { Lithuania }\end{array}$ & Europe & qPCR & 364 & 5 & 1.37 & 8 & {$[71]$} \\
\hline 2005 & Lithuania & Europe & PCR & 62 & 0 & 0 & 7 & [72] \\
\hline 2003-2007 & Netherlands & Europe & RLB/PCR & 1488 & 16 & 1.08 & 7 & [73] \\
\hline NA & Poland & Europe & $\begin{array}{l}\text { Nested } \\
\text { PCR }\end{array}$ & 60 & 35 & 58.33 & 6 & {$[74]$} \\
\hline 2008 & Poland & Europe & $\begin{array}{l}\text { Nested } \\
\text { PCR }\end{array}$ & 1392 & 22 & 1.58 & 8 & [75] \\
\hline 2009-2012 & Poland & Europe & $\begin{array}{l}\text { Nested } \\
\text { PCR }\end{array}$ & 205 & 6 & 2.93 & 5 & [76] \\
\hline 2001 & Poland & Europe & PCR & 1328 & 28 & 2.11 & 7 & [77] \\
\hline 2000-2004 & Poland & Europe & PCR & 1513 & 5 & 0.33 & 8 & [78] \\
\hline 1999 & Poland & Europe & PCR & 2095 & 130 & 6.21 & 8 & [79] \\
\hline 2009-2010 & Poland & Europe & qPCR & 1875 & 47 & 2.51 & 8 & [80] \\
\hline 2009-2010 & Poland & Europe & PCR & 3165 & 50 & 1.58 & 6 & [81] \\
\hline 2008-2009 & Poland & Europe & $\begin{array}{c}\text { PCR, } \\
\text { nested PCR }\end{array}$ & 468 & 21 & 4.49 & 8 & [82] \\
\hline 2011-2012 & Poland & Europe & $\begin{array}{c}\text { PCR, } \\
\text { nested PCR }\end{array}$ & 1435 & 55 & 3.83 & 8 & [83] \\
\hline 2011 & Poland & Europe & PCR & 634 & 26 & 4.10 & 7 & [84] \\
\hline 2004-2006 & Poland & Europe & $\begin{array}{l}\text { Nested } \\
\text { PCR }\end{array}$ & 1620 & 57 & 3.52 & 7 & [85] \\
\hline 2001 & Poland & Europe & $\begin{array}{l}\text { Nested } \\
\text { PCR }\end{array}$ & 701 & 16 & 2.28 & 7 & [86] \\
\hline 2006-2008 & Estonia & Europe & $\begin{array}{c}\text { RLB, } \\
\text { nested PCR }\end{array}$ & 2603 & 36 & 1.38 & 6 & [87] \\
\hline
\end{tabular}


Table 1. Cont.

\begin{tabular}{|c|c|c|c|c|c|c|c|c|}
\hline Study Year & Country & Continent & $\begin{array}{l}\text { Molecular } \\
\text { Technique }\end{array}$ & $\begin{array}{l}\text { Sample } \\
\text { Size }\end{array}$ & Cases & MIR & JBI QAS & Study Ref. \\
\hline 2012 & Portugal & Europe & PCR & 263 & 0 & 0.0 & 8 & [88] \\
\hline 2012-2013 & Portugal & Europe & PCR & 175 & 0 & 0.0 & 8 & [89] \\
\hline 2007 & Luxembourg & Europe & PCR & 1394 & 36 & 2.58 & 7 & [90] \\
\hline 2010 & Romania & Europe & PCR & 40 & 0 & 0 & 8 & [91] \\
\hline 2013-2014 & Sweden & Europe & PCR & 519 & 23 & 4.43 & 7 & [92] \\
\hline 2015-2016 & Sweden & Europe & PCR & 277 & 0 & 0 & 8 & [93] \\
\hline 2000 & Russia & Europe & PCR & 738 & 7 & 0.95 & 6 & [94] \\
\hline 2009 & Russia & Europe & PCR & 481 & 5 & 1.04 & 6 & [95] \\
\hline 2003-2004 & Russia & Europe & $\begin{array}{l}\text { Nested } \\
\text { PCR }\end{array}$ & 209 & 3 & 1.44 & 6 & [22] \\
\hline 2008-2009 & Russia & Europe & $\begin{array}{l}\text { Nested } \\
\text { PCR }\end{array}$ & 922 & 24 & 2.60 & 6 & [96] \\
\hline 2010-2015 & Russia & Europe & $\begin{array}{l}\text { Nested } \\
\text { PCR }\end{array}$ & 911 & 4 & 0.44 & 6 & {$[31]$} \\
\hline 2002 & Slovakia & Europe & PCR & 100 & 1 & 1.0 & 8 & [97] \\
\hline 2011 & Slovakia & Europe & PCR & 5148 & 78 & 1.63 & 8 & [98] \\
\hline 2011-2012 & Slovakia & Europe & PCR & 886 & 12 & 1.35 & 7 & [99] \\
\hline 1997 & Slovenia & Europe & PCR & 135 & 13 & 9.63 & 7 & [100] \\
\hline 2003 & Czech Republic & Europe & PCR & 350 & 5 & 1.43 & 8 & [101] \\
\hline 2011-2014 & Czech Republic & Europe & PCR & 2473 & 32 & 1.29 & 8 & [102] \\
\hline 1997 & Belgium & Europe & PCR & 230 & 0 & 0 & 6 & [103] \\
\hline 2011-2013 & $\begin{array}{l}\text { Netherlands and } \\
\text { Belgium }\end{array}$ & Europe & RLB/PCR & 855 & 17 & 1.99 & 7 & {$[41]$} \\
\hline 2003-2005 & Spain & Europe & RLB/PCR & 562 & 17 & 3.03 & 8 & {$[44]$} \\
\hline 2002-2003 & Switzerland & Europe & PCR & 865 & 4 & 0.46 & 7 & [104] \\
\hline 2006 & Switzerland & Europe & RLB/PCR & 2568 & 44 & 1.71 & 8 & [105] \\
\hline 2009-2010 & Switzerland & Europe & RLB/PCR & 1476 & 28 & 1.89 & 7 & [39] \\
\hline 2015-2016 & Switzerland & Europe & qPCR & 1079 & 6 & 0.56 & 8 & [106] \\
\hline 2012 & Switzerland & Europe & PCR & 261 & 16 & 6.13 & 8 & [23] \\
\hline 2013-2014 & Ukraine & Europe & PCR & 767 & 13 & 1.69 & 7 & [107] \\
\hline 2011-2013 & Turkey & $\begin{array}{l}\text { Europe- } \\
\text { Asia }\end{array}$ & NGS & 205 & 1 & 0.49 & 7 & [33] \\
\hline 2014-2018 & Turkey & $\begin{array}{l}\text { Europe- } \\
\text { Asia }\end{array}$ & PCR & 1019 & 27 & 2.65 & 8 & [108] \\
\hline 2013-2014 & China & Asia & RLB/PCR & 450 & 37 & 8.22 & 8 & [43] \\
\hline 2013-2014 & China & Asia & $\begin{array}{l}\text { Nested } \\
\text { PCR }\end{array}$ & 558 & 2 & 0.36 & 8 & [8] \\
\hline 2013-2014 & China & Asia & $\begin{array}{l}\text { Nested } \\
\text { PCR }\end{array}$ & 797 & 51 & 6.39 & 7 & [28] \\
\hline 2013-2014 & Israel & Asia & PCR & 1196 & 3 & 0.25 & 6 & [109] \\
\hline 2013-2015 & Japan & Asia & $\begin{array}{l}\text { Nested } \\
\text { PCR }\end{array}$ & 624 & 5 & 0.80 & 8 & [110] \\
\hline 2000-2003 & Japan & Asia & $\begin{array}{l}\text { Nested } \\
\text { PCR }\end{array}$ & 1656 & 40 & 2.42 & 8 & [37] \\
\hline 2008 & Japan & Asia & PCR & 1459 & 18 & 1.23 & 8 & [29] \\
\hline 2000-2003 & Japan & Asia & PCR & 294 & 17 & 5.78 & 8 & {$[30]$} \\
\hline NA & Mongolia & Asia & $\begin{array}{l}\text { Nested } \\
\text { PCR }\end{array}$ & 108 & 7 & 6.48 & 6 & [45] \\
\hline 2009 & Mongolia & Asia & PCR & 400 & 9 & 2.25 & 8 & [111] \\
\hline 2012-2013 & Mongolia & Asia & $\begin{array}{l}\text { Nested } \\
\text { PCR }\end{array}$ & 219 & 19 & 8.68 & 7 & [32] \\
\hline 2015 & Thailand & Asia & PCR & 12,184 & 1 & 0.01 & 8 & [112] \\
\hline 2009 & Nigeria & Africa & PCR & 700 & 0 & 0 & 8 & {$[34]$} \\
\hline
\end{tabular}


Table 1. Cont.

\begin{tabular}{|c|c|c|c|c|c|c|c|c|}
\hline Study Year & Country & Continent & $\begin{array}{l}\text { Molecular } \\
\text { Technique }\end{array}$ & $\begin{array}{c}\text { Sample } \\
\text { Size }\end{array}$ & Cases & MIR & JBI QAS & Study Ref. \\
\hline 2001 & $\begin{array}{c}\text { United States of } \\
\text { America }\end{array}$ & $\begin{array}{l}\text { North } \\
\text { America }\end{array}$ & PCR & 107 & 9 & 8.41 & 6 & [113] \\
\hline 2013-2014 & $\begin{array}{c}\text { United States of } \\
\text { America }\end{array}$ & $\begin{array}{l}\text { North } \\
\text { America }\end{array}$ & PCR & 423 & 3 & 0.71 & 6 & [114] \\
\hline 1985 & $\begin{array}{c}\text { United States of } \\
\text { America }\end{array}$ & $\begin{array}{l}\text { North } \\
\text { America }\end{array}$ & PCR & 395 & 48 & 12.15 & 8 & [115] \\
\hline 1996 & $\begin{array}{c}\text { United States of } \\
\text { America }\end{array}$ & $\begin{array}{l}\text { North } \\
\text { America }\end{array}$ & PCR & 100 & 5 & 5.0 & 6 & [116] \\
\hline 2003-2006 & $\begin{array}{c}\text { United States of } \\
\text { America }\end{array}$ & $\begin{array}{l}\text { North } \\
\text { America }\end{array}$ & PCR & 394 & 41 & 10.41 & 7 & [117] \\
\hline 2003 & $\begin{array}{c}\text { United States of } \\
\text { America }\end{array}$ & $\begin{array}{l}\text { North } \\
\text { America }\end{array}$ & PCR & 68 & 7 & 10.29 & 6 & [42] \\
\hline 2015-2017 & $\begin{array}{c}\text { United States of } \\
\text { America }\end{array}$ & $\begin{array}{l}\text { North } \\
\text { America }\end{array}$ & HRM & 1721 & 62 & 3.60 & 8 & [118] \\
\hline 2010 & $\begin{array}{c}\text { United States of } \\
\text { America }\end{array}$ & $\begin{array}{c}\text { North } \\
\text { America }\end{array}$ & PCR & 191 & 0 & 0 & 8 & [119] \\
\hline 2012-2014 & $\begin{array}{c}\text { United States of } \\
\text { America }\end{array}$ & $\begin{array}{l}\text { North } \\
\text { America }\end{array}$ & qPCR & 1855 & 54 & 2.91 & 8 & [120] \\
\hline 2003-2004 & $\begin{array}{c}\text { United States of } \\
\text { America }\end{array}$ & $\begin{array}{c}\text { North } \\
\text { America }\end{array}$ & $\begin{array}{l}\text { Multiplex } \\
\text { PCR }\end{array}$ & 11,184 & 283 & 2.53 & 8 & [27] \\
\hline 2011 & $\begin{array}{c}\text { United States of } \\
\text { America }\end{array}$ & $\begin{array}{l}\text { North } \\
\text { America }\end{array}$ & PCR & 1245 & 35 & 2.81 & 7 & [35] \\
\hline 2011 & $\begin{array}{c}\text { United States of } \\
\text { America }\end{array}$ & $\begin{array}{l}\text { North } \\
\text { America }\end{array}$ & qPCR & 4368 & 255 & 5.84 & 8 & [121] \\
\hline 2016-2017 & Canada & $\begin{array}{l}\text { North } \\
\text { America }\end{array}$ & PCR & 249 & 4 & 1.61 & 8 & [26] \\
\hline
\end{tabular}

PCR: polymerase chain reaction; qPCR: real-time polymerase chain reaction; RLB: reverse line blotting; HRM: high-resolution melting; NGS: next-generation sequencing; NA: not available; MIR: minimum infection rate; JBI: Joanna Briggs Institute; QAS: quality assessment score. * Sprong et al. (2019): The sample number and results from Germany were excluded from our computation.

\subsection{Characteristics of Eligible Studies}

The characteristics of all eligible studies comprising of 137,364 ticks from 104 studies across different regions of the world are presented in Table 1. Included studies were from Europe $(n=78)$, North America $(n=13)$, Asia $(n=12)$, and Africa $(n=1)$. All eligible studies were carried out using molecular techniques to screen for tick-borne pathogens with particular reference to Babesia species. The prevalence for all the individual studies was computed and presented in Table 1. Individually, apart from a few studies, which recorded a $0 \%$ prevalence, the majority of the studies ranges from $0.25 \%$ to $12.96 \%$, with a median of $1.78 \%$. There were two studies with a prevalence of $20.65 \%$ and $21.67 \%$ and another two studies with a prevalence of $51.04 \%$ and $58.33 \%$ (Table 1 ). The majority of the studies were carried out from the year 2000 onward, with only one study undertaken in 1985.

\subsection{Pooling, Heterogeneity and Subgroup Analysis}

2.3.1. Prevalence Based on Tick Species, Life Stages, Sex, and Diagnostic Technique

The overall and subgroup prevalence estimates of Babesia spp. based on tick species, life stages, sex and diagnostic technique, including confidence intervals and statistical parameters, are presented in Table 2. Globally, the overall pooled prevalence estimated (PPE) for Babesia species in questing ticks was 2.10\% for all studies with 3069 positive cases from a total of 137,364 ticks screened and substantial study heterogeneity was observed (Table 2; Figure 2). Babesia species were detected in 23 different tick species within 4 genera Ixodes (5 species), Dermacentor (4 species), Rhipicephalus (4 species), Haemaphysalis (9 species) and Hyalomma (1 species) (Table 2). Ixodes ricinus was the most collected tick species with over 74,802 ticks in number and 1756 positive cases with PPE at 2.40\% (Table 2; 
Figure 3). Other tick species included: I. persulcatus with PPE at 1.50\%, I. scapularis at $4.10 \%$, D. reticulatus at $2.10 \%$, and H. longicornis at $4.30 \%$ (Table 2 ).

Table 2. Pooled minimum infection rate (MIR) estimates of Babesia spp. in questing ticks based on tick species, life stages, sex, and diagnostic technique.

\begin{tabular}{|c|c|c|c|c|c|c|c|}
\hline \multirow[b]{2}{*}{ Subgroup } & \multirow[b]{2}{*}{$\begin{array}{l}\text { Number of } \\
\text { Studies }\end{array}$} & \multicolumn{3}{|c|}{ Pooled Prevalence Estimates } & \multicolumn{3}{|c|}{ Measure of Heterogeneity } \\
\hline & & Sample Size & No of Positives & $\begin{array}{c}\text { Weighted } \\
\text { MIR95\% CI (\%) }\end{array}$ & $Q$ Value & $I^{2}$ & $Q-p$ \\
\hline All studies & 104 & 137,364 & 3069 & $2.10(1.60-2.70)$ & 4438.97 & 97.65 & $p<0.0001$ \\
\hline \multicolumn{8}{|l|}{ Tick species } \\
\hline Ixodes ricinus & 57 & 74,802 & 1756 & $2.40(1.50-3.60)$ & 3737.86 & 98.50 & $p<0.0001$ \\
\hline I. persulcatus & 14 & 5823 & 102 & $1.50(0.70-3.20)$ & 154.44 & 91.58 & $p<0.0001$ \\
\hline I. ovatus & 3 & 1420 & 39 & $0.60(0.00-9.20)$ & 17.23 & 88.39 & $p<0.0001$ \\
\hline I. scapularis & 14 & 22,694 & 786 & $4.10(2.70-6.20)$ & 296.36 & 95.95 & $p<0.0001$ \\
\hline I. pavlovskyi & 1 & 577 & 2 & $0.30(0.01-1.40)$ & - & - & - \\
\hline $\begin{array}{l}\text { Dermacentor } \\
\text { reticulatus }\end{array}$ & 20 & 11,802 & 197 & $2.10(1.30-3.50)$ & 174.89 & 89.14 & $p<0.0001$ \\
\hline D. marginatus & 2 & 390 & 1 & $0.80(0.10-9.4)$ & 2.26 & 55.65 & $p<0.0001$ \\
\hline D. nuttalli & 3 & 389 & 7 & $1.30(0.10-12.10)$ & 7.60 & 73.76 & $p=0.022$ \\
\hline D. silvarum & 2 & 223 & 4 & $1.80(0.20-18.50)$ & 3.06 & 67.23 & $p=0.080$ \\
\hline R. bursa & 4 & 120 & 2 & $2.90(0.90-8.50)$ & 0.99 & 0.00 & $p=0.802$ \\
\hline R. sanguineus s.l. & 5 & 1668 & 3 & $0.60(0.10-2.60)$ & 8.77 & 54.39 & $p<0.001$ \\
\hline $\begin{array}{l}\text { R. (Boophilus) } \\
\text { microplus }\end{array}$ & 3 & 1498 & 2 & $0.30(0.10-1.90)$ & 1.63 & 0.00 & $p=0.443$ \\
\hline R. turanicus & 1 & 9 & 1 & $11.1(1.50-50.00)$ & 0.00 & 0.00 & $p=1.000$ \\
\hline $\begin{array}{l}\text { Hemaphysalis } \\
\text { longicornis }\end{array}$ & 5 & 626 & 28 & $4.30(1.60-10.90)$ & 13.17 & 69.62 & $p=0.010$ \\
\hline H. concinna & 4 & 130 & 6 & $6.10(3.00-11.90)$ & 0.760 & 0.00 & $p=0.825$ \\
\hline H. qinghaiensis & 2 & 430 & 73 & $17.20(10.90-26.0)$ & 4.32 & 76.86 & $p=0.038$ \\
\hline H. punctata & 1 & 111 & 4 & $3.60(1.40-9.20)$ & 0.00 & 0.00 & $p=1.000$ \\
\hline H. parva & 1 & 793 & 13 & $1.60(1.00-2.80)$ & 0.00 & 0.00 & $p=1.000$ \\
\hline H. inermis & 1 & 87 & 1 & $1.10(0.20-7.70)$ & 0.00 & 0.00 & $p=1.000$ \\
\hline H. flava & 2 & 282 & 3 & $1.30(0.50-3.80)$ & 0.49 & - & $p=0.484$ \\
\hline H. formosensis & 1 & 159 & 2 & $1.30(0.30-4.90)$ & 0.00 & 0.00 & $p=1.000$ \\
\hline H. lagrangei & 1 & 11,309 & 1 & $0.00(0.00-0.01)$ & 0.00 & 0.00 & $p=1.000$ \\
\hline $\begin{array}{l}\text { Hyalomma } \\
\text { marginatum }\end{array}$ & 1 & 105 & 13 & $12.38(7.30-20.20)$ & 0.00 & 0.00 & $p=1.000$ \\
\hline
\end{tabular}


Table 2. Cont.

\begin{tabular}{|c|c|c|c|c|c|c|c|}
\hline \multirow[b]{2}{*}{ Subgroup } & \multirow[b]{2}{*}{$\begin{array}{l}\text { Number of } \\
\text { Studies }\end{array}$} & \multicolumn{3}{|c|}{ Pooled Prevalence Estimates } & \multicolumn{3}{|c|}{ Measure of Heterogeneity } \\
\hline & & Sample Size & No of Positives & $\begin{array}{c}\text { Weighted } \\
\text { MIR95\% CI (\%) }\end{array}$ & $Q$ Value & $I^{2}$ & $Q-p$ \\
\hline \multicolumn{8}{|l|}{ Life stages } \\
\hline Adult & 79 & 55,411 & 1484 & $2.60(2.00-3.40)$ & 1693.34 & 95.34 & $p<0.0001$ \\
\hline Nymphs & 53 & 44,746 & 1066 & $1.70(1.10-2.50)$ & 1578.82 & 96.77 & $p<0.0001$ \\
\hline Larvae & 13 & 20,866 & 174 & $0.60(0.10-3.60)$ & 699.77 & 98.29 & $p<0.0001$ \\
\hline \multicolumn{8}{|l|}{ Sex } \\
\hline Male & 26 & 7534 & 199 & $3.60(3.10-4.20)$ & 145.53 & 82.82 & $p<0.0001$ \\
\hline Female & 26 & 8395 & 275 & $4.90(4.40-5.60)$ & 256.98 & 90.27 & $p<0.0001$ \\
\hline \multicolumn{8}{|c|}{ Diagnostic technique } \\
\hline $\begin{array}{c}\text { Conventional } \\
\text { PCR }\end{array}$ & 66 & 76,021 & 1663 & $1.90(1.30-2.90)$ & 3339.99 & 98.05 & $p<0.0001$ \\
\hline qPCR & 12 & 23,314 & 522 & $1.70(1.00-3.00)$ & 332.86 & 96.69 & $p<0.0001$ \\
\hline Nested PCR & 16 & 14,653 & 376 & $2.80(1.70-4.70)$ & 339.97 & 95.59 & $p<0.0001$ \\
\hline RLB & 7 & 10,002 & 195 & $2.20(1.30-3.80)$ & 85.88 & 92.99 & $p<0.0001$ \\
\hline Multiplex PCR & 2 & 13,115 & 246 & $1.90(1.70-2.10)$ & 0.89 & 0.00 & $p=0.344$ \\
\hline NGS & 1 & 205 & 2 & $1.00(0.20-3.80)$ & 0.00 & 0.00 & $p=1.000$ \\
\hline
\end{tabular}

PCR: polymerase chain reaction; qPCR: real-time polymerase chain reaction; RLB: reverse line blotting; NGS: next-generation sequencing; $I^{2}$ : inverse variance; $Q-p$ : Cochran's; CI: confidence interval; MIR: minimum infection rate. Measure of heterogeneity: the weighted sum of squared differences between individual study effects and the pooled effect across studies.

Other tick species that were reported, but no Babesia species were detected: $H$. sp. 1 \& 2 [8]; H. bispinosa [28]; Hy. spp. [109]; H. hystricis and H. kitaokai [110]; Amblyomma testudinarium [110]; I. nipponensis [110]; I. turdus [37,110]; I. tanuki [37]; H. douglasi [29,37]; H. megaspinosa [29]; H. wellingtoni [112].

With regard to tick life stages, we observed an increasing infection rate from larvae with $0.60 \%$ to nymphs with $1.70 \%$ and the highest in adults with $2.60 \%$ (Table 2). Statistically significant differences $(p<0.0001)$ were observed across the different life stages. Additionally, the infection rate between the adult and larva was significantly different $(p=0.0033)$. The PPE was significantly $(p=0.0211)$ higher in the females with $4.90 \%$ compared to the males with $3.60 \%$ (Table 2).

Six different molecular diagnostic techniques were employed in all the included studies, with conventional PCR being the most widely utilized in 66 studies with a PPE of $1.90 \%$. Others include nested-PCR with $2.80 \%$ and qPCR with $1.70 \%$ (Table 2, Figure 4). 


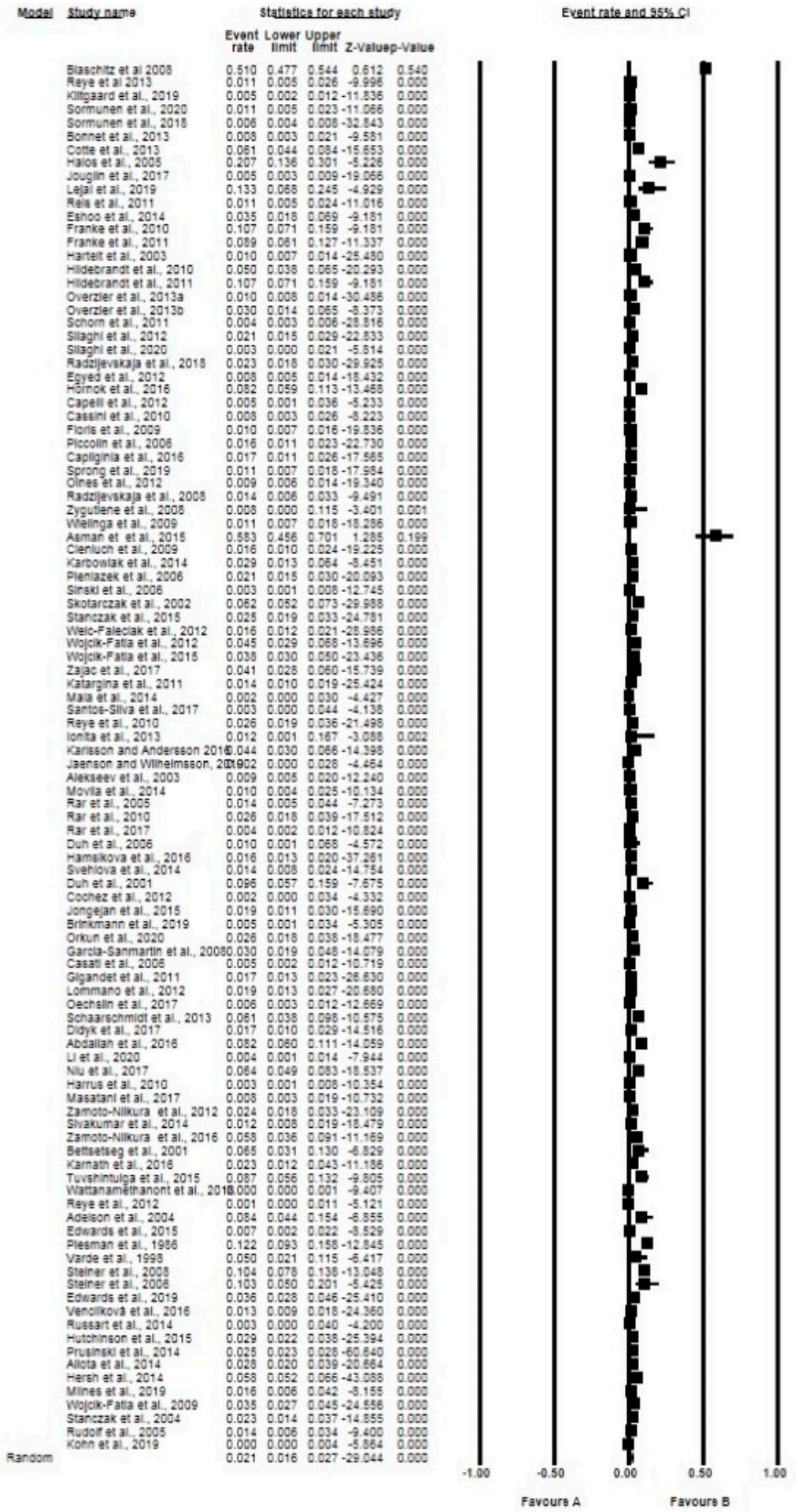

Figure 2. Forest plot showing the pooled prevalence of Babesia species globally. N.B. The squares show the individual point estimate. The diamond at the base indicate the pooled estimates from the total studies. Event rate: the frequency of occurrence of an event in a population, and it takes into account the possibility of an event occurring several times in an individual. 


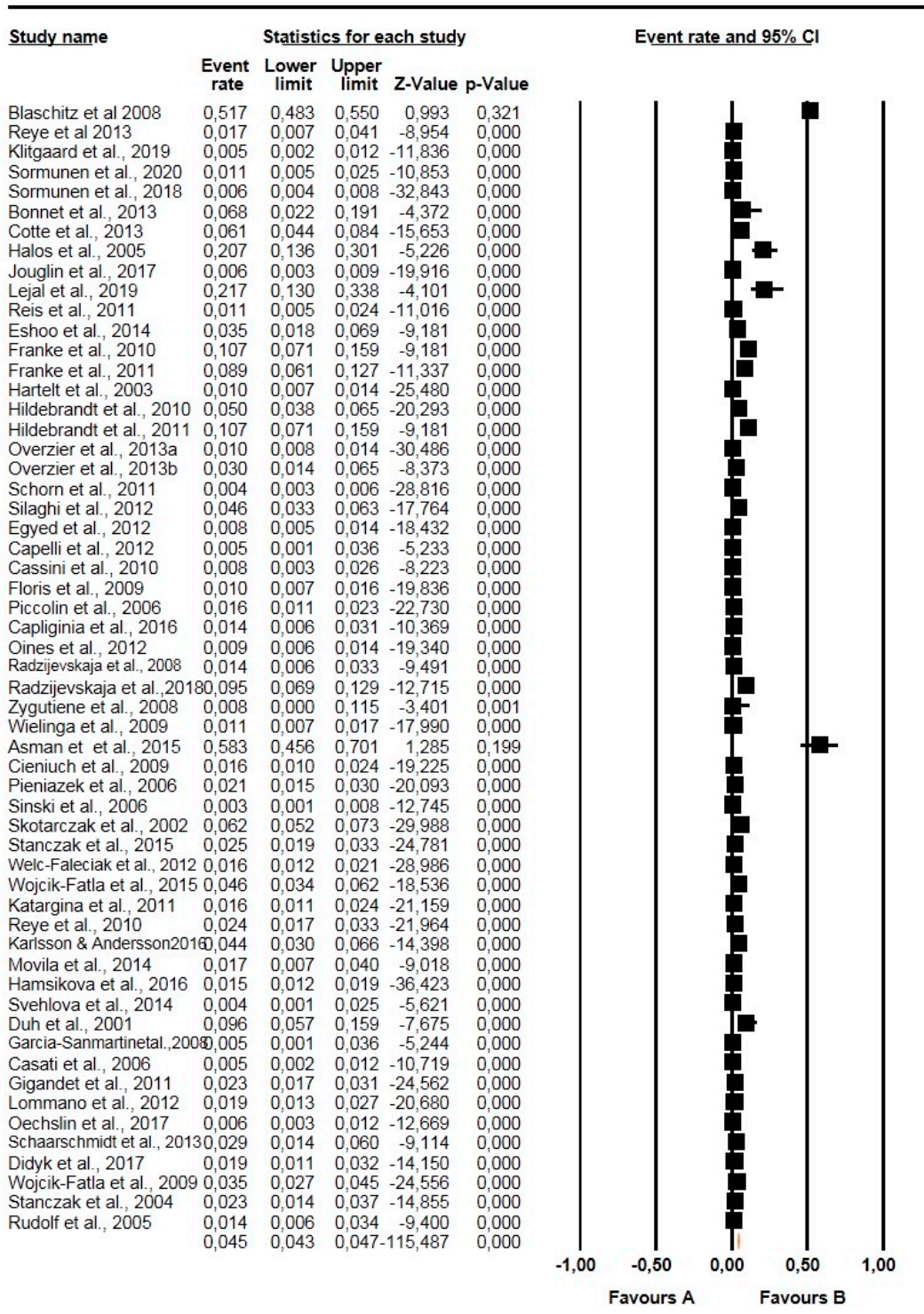

Figure 3. Forest plot showing the prevalence of Babesia species in questing Ixodes ricinus in Europe. N.B. The squares show the individual point estimate. The diamond at the base indicate the pooled estimates from the total studies. Event rate: is the frequency of occurrence of an event in a population, and it takes into account the possibility of an event occurring several times in an individual.

\subsubsection{Prevalence Based on Babesia Species, Region, and Sampling Periods}

Globally, 19 different Babesia species were identified in ticks, with B. microti being the most observed species in 46 studies with a PPE of $1.90 \%$ (Table 3; Figure 5). This was followed by $B$. venatorum with $0.90 \%$ and $B$. divergens with $0.40 \%$, which were exclusively found in ticks from Europe except for one study from Mongolia where B. venatorum DNA was amplified (Table 3). The prevalence of B. ovata was $0.60 \%$, and B. spp. Xinjiang with $6.70 \%$ was observed only in ticks collected from Asia (Table 3). 


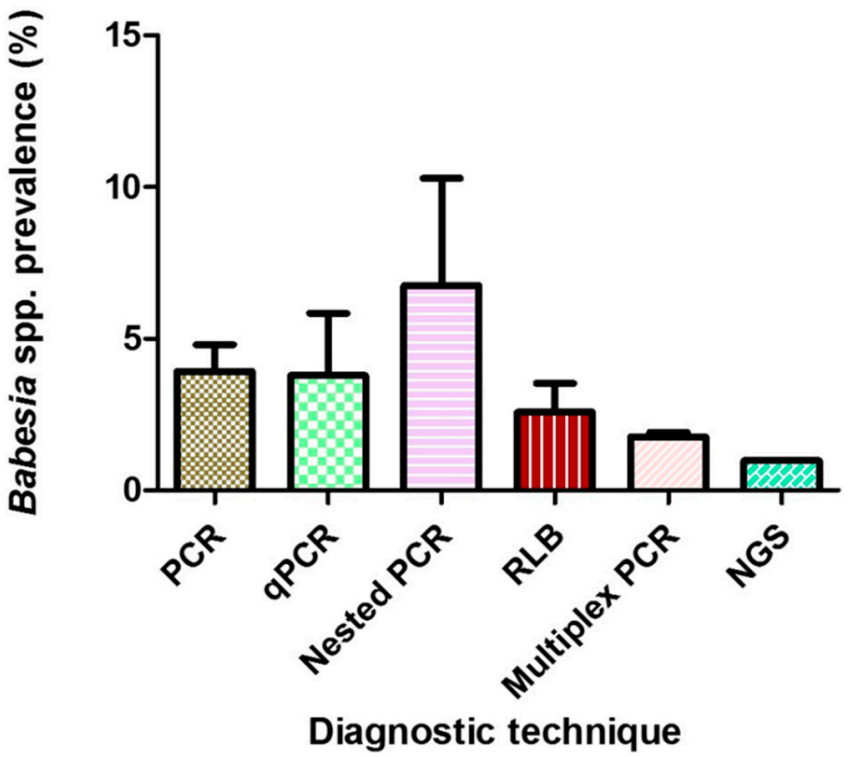

Figure 4. Mean prevalences of Babesia species globally using different diagnostic techniques. Error bars, standard errors of the means.

Table 3. Pooled MIR estimates of Babesia in questing ticks based on Babesia species, region, and sampling periods.

\begin{tabular}{|c|c|c|c|c|c|c|c|}
\hline \multirow[b]{2}{*}{ Subgroup } & \multirow[b]{2}{*}{$\begin{array}{l}\text { Number of } \\
\text { Studies }\end{array}$} & \multicolumn{3}{|c|}{ Pooled Prevalence Estimates } & \multicolumn{3}{|c|}{ Measure of Heterogeneity } \\
\hline & & Sample Size & $\begin{array}{c}\text { No of } \\
\text { Positives }\end{array}$ & $\begin{array}{c}\text { Weighted } \\
\text { MIR95\% CI (\%) }\end{array}$ & $Q$ Value & $I^{2}$ & $Q-p$ \\
\hline All studies & 104 & 137,364 & 3069 & $2.10(1.60-2.70)$ & 4438.41 & 97.68 & $p<0.0001$ \\
\hline \multicolumn{8}{|l|}{ Babesia species } \\
\hline Babesia microti & 46 & 68,537 & 1425 & $1.90(1.40-2.50)$ & 1071.94 & 95.80 & $p<0.0001$ \\
\hline B. venatorum & 31 & 50,611 & 370 & $0.90(0.70-1.10)$ & 163.47 & 81.65 & $p<0.0001$ \\
\hline B. divergens & 20 & 33,517 & 141 & $0.40(0.20-0.70)$ & 161.75 & 88.47 & $p<0.0001$ \\
\hline B. spp. & 19 & 38,125 & 183 & $0.50(0.20-1.10)$ & 363.19 & 95.59 & $p<0.0001$ \\
\hline B. capreoli & 6 & 15,927 & 13 & $0.10(0.10-0.20)$ & 7.31 & 31.61 & $p=0.199$ \\
\hline B. canis & 15 & 14,938 & 132 & $1.10(0.50-2.40)$ & 235.83 & 94.06 & $p<0.0001$ \\
\hline B. odocoilei & 6 & 8002 & 52 & $0.90(0.20-4.50)$ & 102.06 & 95.10 & $p<0.0001$ \\
\hline B. caballi & 3 & 1525 & 17 & $1.40(0.30-6.90)$ & 20.02 & 90.01 & $p<0.0001$ \\
\hline B. bovis & 2 & 1012 & 3 & $0.30(0.10-0.90)$ & 0.15 & 0.00 & $p=0.700$ \\
\hline B. bigemina & 3 & 1570 & 7 & $0.50(0.20-1.40)$ & 2.75 & 27.16 & $p=0.253$ \\
\hline B. ovata & 2 & 1909 & 18 & $0.60(0.10-5.00)$ & 2.85 & 64.87 & $p=0.092$ \\
\hline B. spp. Xinjiang & 2 & 1247 & 84 & $6.70(5.50-8.30)$ & 0.39 & 0.00 & $p=0.528$ \\
\hline B. gibsoni & 1 & 6593 & 1 & $0.00(0.00-0.10)$ & 0.00 & 0.00 & $p=1.000$ \\
\hline B. ovis & 1 & 205 & 1 & $0.50(0.10-3.40)$ & 0.00 & 0.00 & $p=1.000$ \\
\hline B. occultans & 1 & 1019 & 12 & $1.20(0.70-2.10)$ & - & - & - \\
\hline B. rossi & 1 & 1019 & 4 & $0.40(0.10-1.00)$ & 0.00 & 0.00 & $p=1.000$ \\
\hline B. vogeli & 1 & 1196 & 3 & $1.50(0.00-32.40)$ & & & \\
\hline B. crassa & 1 & 1019 & 8 & $0.80(0.40-1.60)$ & 0.00 & 0.00 & $p=1.000$ \\
\hline B. motasi like & 1 & 450 & 3 & $0.70(0.20-2.00)$ & 0.00 & 0.00 & $p=1.000$ \\
\hline
\end{tabular}


Table 3. Cont.

\begin{tabular}{|c|c|c|c|c|c|c|c|}
\hline \multirow[b]{2}{*}{ Subgroup } & \multirow[b]{2}{*}{$\begin{array}{c}\text { Number of } \\
\text { Studies }\end{array}$} & \multicolumn{3}{|c|}{ Pooled Prevalence Estimates } & \multicolumn{3}{|c|}{ Measure of Heterogeneity } \\
\hline & & Sample Size & $\begin{array}{c}\text { No of } \\
\text { Positives }\end{array}$ & $\begin{array}{c}\text { Weighted } \\
\text { MIR95\% CI (\%) }\end{array}$ & $Q$ Value & $I^{2}$ & $Q-p$ \\
\hline \multicolumn{8}{|l|}{ Region } \\
\hline Europe & 78 & 94,376 & 2056 & $1.90(1.30-2.70)$ & 3964.12 & 98.06 & $p<0.0001$ \\
\hline Asia & 12 & 19,945 & 209 & $2.00(1.10-3.50)$ & 174.67 .69 & 93.70 & $p<0.0001$ \\
\hline North America & 13 & 22,299 & 806 & $4.30(3.00-6.20)$ & 237.73 & 94.95 & $p<0.0001$ \\
\hline \multicolumn{8}{|l|}{$\begin{array}{c}\text { Sampling } \\
\text { period }\end{array}$} \\
\hline $\begin{array}{l}1992-1997 \\
(\text { period 1) }\end{array}$ & 3 & 465 & 18 & $4.30(1.30-13.90)$ & 8.28 & 75.85 & $p=0.016$ \\
\hline $\begin{array}{l}1998-2002 \\
(\text { period } 2)\end{array}$ & 9 & 10,205 & 269 & $2.90(1.40-5.70)$ & 205.79 & 96.11 & $p<0.0001$ \\
\hline $\begin{array}{l}2003-2008 \\
\text { (period 3) }\end{array}$ & 29 & 39,266 & 1326 & $2.60(1.40-4.80)$ & 2628.50 & 98.94 & $p<0.0001$ \\
\hline $\begin{array}{l}2009-2014 \\
\text { (period 4) }\end{array}$ & 38 & 52,571 & 950 & $1.60(1.20-2.20)$ & 627.33 & 94.10 & $p<0.0001$ \\
\hline $\begin{array}{l}2015-2020 \\
\text { (period 5) }\end{array}$ & 10 & 20,722 & 103 & $0.90(0.40-2.10)$ & 112.84 & 92.91 & $p<0.0001$ \\
\hline
\end{tabular}

$\mathrm{I}^{2}$ : inverse variance; $Q-p$ : Cochran's; CI: confidence interval; MIR: minimum infection rate. Measure of heterogeneity: the weighted sum of squared differences between individual study effects and the pooled effect across studies.

According to region, Europe accounted for the majority of the studies $(n=78)$ with a PPE of $1.90 \%$ compared with Asia $(n=12)$ with a PPE of $2.00 \%$ (Table 3$)$. North America had the highest PPE of $4.30 \%$ (Table 3). A single study was eligible from Africa, but none of the ticks was positive for Babesia spp.

We observed a statistically significant $(p<0.001)$ downward trend with respect to the PPE, with the highest being in period 1 (1992-1997) and the lowest in period 5 (2015-2020) (Table 3).

\subsubsection{Species Diversity of Babesia within Different Tick Species}

The results of the distribution of different Babesia species according to the different tick species are presented in Figure 6. Ixodes ricinus was associated with 9 different Babesia spp. with $B$. microti and B. venatorum having the highest number of isolates: 523 and 359, respectively (Figure 6). Furthermore, I. persulcatus and I. scapularis ticks were associated with 5 and 3 different Babesia species, respectively, with a total of 911 Babesia isolates shared between both ticks. Additionally, B. microti accounted for 746 Babesia isolates in I. scapularis. Finally, D. reticulatus was associated with 6 different Babesia species, with $B$. canis being the highest with 126 isolates (Figure 6). 


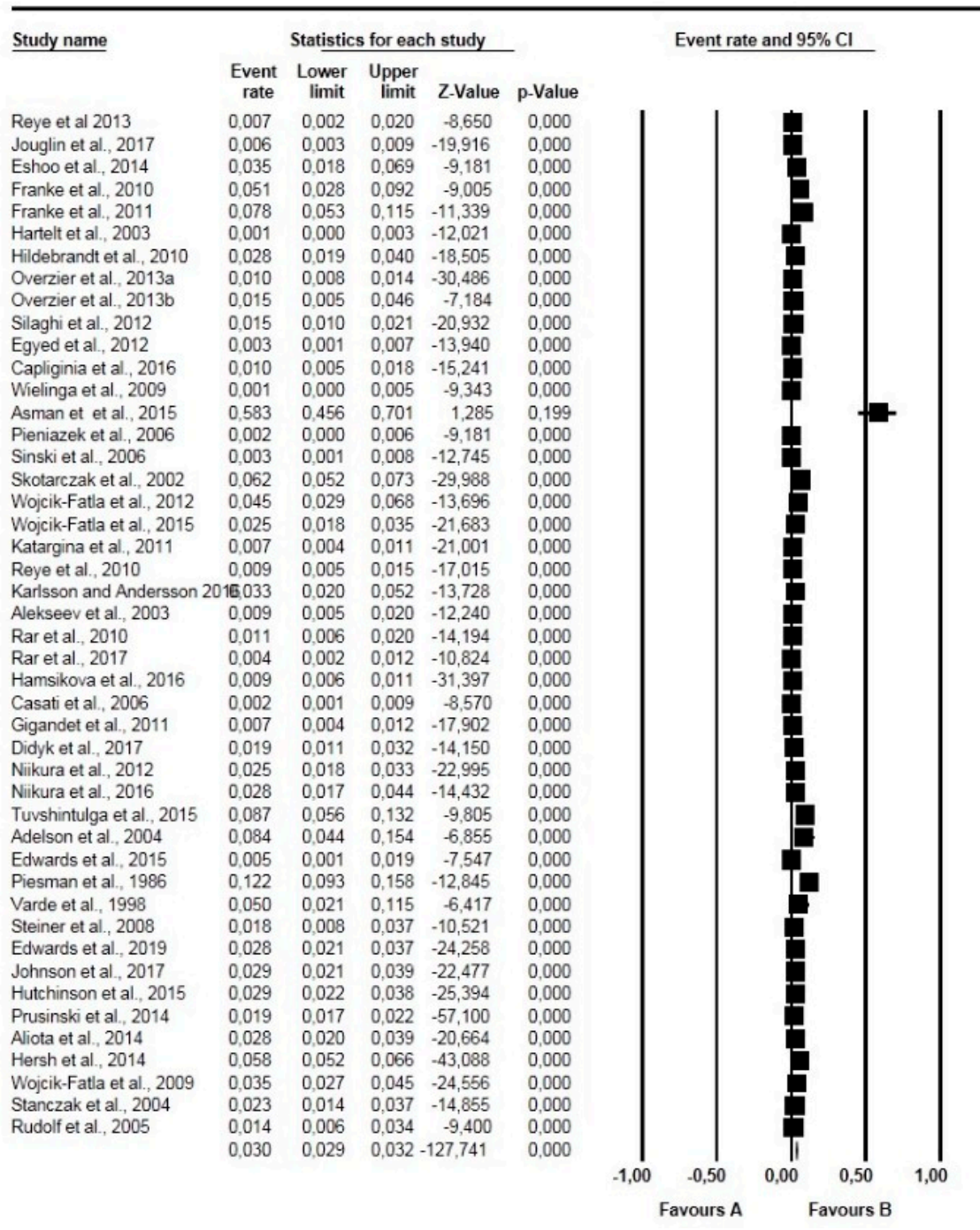

Figure 5. Forest plot showing the prevalence of Babesia microti globally. N.B. The squares show the individual point estimate. The diamond at the base indicate the pooled estimates from the total studies.

\subsection{Spatial Distribution of Eligible Studies}

In total, the results for 36 individual countries across four continents are presented in Table 4. In Europe, Poland and Germany had the highest number of eligible studies with 13 and 12 entries, each with PPE of $3.40 \%$ and $2.20 \%$, respectively (Table 4). In addition, United States had 12 eligible studies with a PPE of $4.30 \%$. Some other countries, including France, Russia, and Switzerland, have a PPE of 3.30\%, $1.20 \%$ and $1.50 \%$, respectively. A map with the spatial distribution of Babesia spp. across the different countries in Europe in different tick species is shown in Figure 7. 
Rhipicephalus turanicus Rhipicephalus sanguineus s.l. -

Rhipicephalus microplus - 2

Rhipicephalus bursa Ixodes scapularisIxodes ricinus Ixodes persulcatus Ixodes pavlovskyi Ixodes ovatus Hyalomma marginatum Haemaphysalis qinghaiensis Haemaphysalis punctata- 1112

Haemaphysalis parvaHaemaphysalis longicornis Haemaphysalis lagrangeiHaemaphysalis inermis - 1 Haemaphysalis formosensis Haemaphysalis flavaHaemaphysalis concinnaDermacentor silvarum Dermacentor reticulatus Dermacentor nuttalli Dermacentor marginatus -

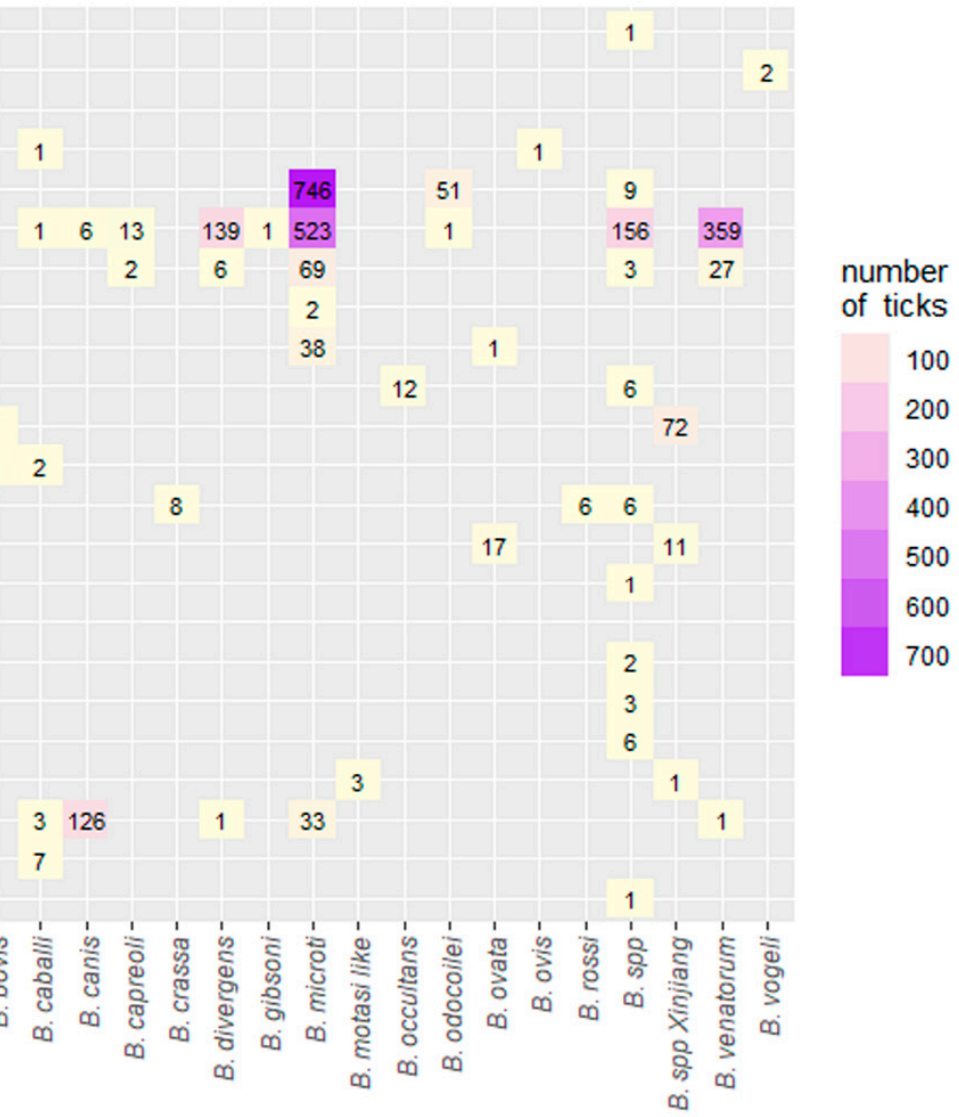

Figure 6. Heat map of the association of different Babesia species in different tick species globally.

Table 4. Prevalence estimates of Babesia in questing ticks based on country.

\begin{tabular}{|c|c|c|c|c|c|c|c|}
\hline \multirow[b]{2}{*}{ Subgroup } & \multirow[b]{2}{*}{$\begin{array}{l}\text { Number of } \\
\text { Studies }\end{array}$} & \multicolumn{3}{|c|}{ Pooled Prevalence Estimates } & \multicolumn{3}{|c|}{ Measure of Heterogeneity } \\
\hline & & Sample Size & No of Positives & $\begin{array}{c}\text { Weighted } \\
\text { MIR95\% CI (\%) }\end{array}$ & $Q$ Value & $\mathrm{I}^{2}$ & $Q-p$ \\
\hline Austria & 1 & 864 & 441 & $51.00(47.70-54.40)$ & - & - & - \\
\hline Belarus & 1 & 453 & 5 & $1.10(0.50-2.60)$ & - & - & - \\
\hline Denmark & 1 & 1013 & 5 & $0.50(0.20-1.20)$ & - & - & - \\
\hline Finland & 2 & 7585 & 47 & $0.70(0.40-1.40)$ & 2.56 & 60.97 & $p=0.109$ \\
\hline France & 6 & 4397 & 87 & $3.30(0.90-10.80)$ & 148.22 & 96.62 & $p<0.0001$ \\
\hline Germany & 12 & 20,257 & 273 & $2.20(1.10-4.40)$ & 326.82 & 96.63 & $p<0.0001$ \\
\hline Hungary & 2 & 2213 & 49 & $2.70(0.30-22.0)$ & 56.48 & 98.23 & $p<0.0001$ \\
\hline Italy & 4 & 4339 & 54 & $1.20(0.90-1.70)$ & 3.93 & 23.64 & $p=0.269$ \\
\hline Latvia & 2 & 1306 & 24 & $1.90(1.30-2.80)$ & 0.98 & 0.00 & $p=0.323$ \\
\hline Norway & 2 & 2132 & 19 & $0.90(0.60-1.40)$ & 0.00 & 0.00 & $p=0.998$ \\
\hline Lithuania & 3 & 2831 & 64 & $2.30(1.80-2.90)$ & 0.59 & 0.00 & $p=0.042$ \\
\hline Netherland & 3 & 2893 & 32 & $1.20(0.40-3.50)$ & 13.34 & 85.01 & $p=0.000$ \\
\hline Poland & 13 & 16,491 & 498 & $3.40(2.10-5.50)$ & 330.43 & 96.37 & $p<0.0001$ \\
\hline Estonia & 1 & 2603 & 36 & $1.40(1.00-1.90)$ & - & - & - \\
\hline Portugal & 2 & 438 & 0 & $0.02(0.00-1.60)$ & 0.041 & 0.00 & $p=0.839$ \\
\hline Luxembourg & 1 & 1394 & 36 & $2.60(1.90-3.60)$ & 0.00 & 0.00 & - \\
\hline
\end{tabular}


Table 4. Cont.

\begin{tabular}{|c|c|c|c|c|c|c|c|}
\hline \multirow[b]{2}{*}{ Subgroup } & \multirow[b]{2}{*}{$\begin{array}{l}\text { Number of } \\
\text { Studies }\end{array}$} & \multicolumn{3}{|c|}{ Pooled Prevalence Estimates } & \multicolumn{3}{|c|}{ Measure of Heterogeneity } \\
\hline & & Sample Size & No of Positives & $\begin{array}{c}\text { Weighted } \\
\text { MIR95\% CI (\%) }\end{array}$ & $Q$ Value & $\mathbf{I}^{2}$ & $Q-p$ \\
\hline Romania & 1 & 40 & 0 & $1.20(0.10-16.70)$ & - & - & - \\
\hline Sweden & 2 & 796 & 23 & $1.20(0.10-22.0)$ & 5.14 & 80.53 & $p=0.023$ \\
\hline Russia & 5 & 3261 & 43 & $1.20(0.60-2.30)$ & 15.48 & 74.15 & $p=0.004$ \\
\hline Slovakia & 3 & 6130 & 97 & $1.60(1.30-1.90)$ & 0.57 & 0.00 & $p=0.751$ \\
\hline Slovenia & 1 & 135 & 13 & $7.40(4.00-13.20)$ & - & - & - \\
\hline Czech Republic & 2 & 2823 & 37 & $1.30(1.00-1.80)$ & 0.04 & 0.00 & $p=0.836$ \\
\hline Belgium & 3 & 1053 & 1 & $0.20(0.10-0.90)$ & 0.54 & 0.00 & $p=0.761$ \\
\hline Britain & 1 & 113 & 16 & $14.20(8.90-21.90)$ & - & - & - \\
\hline Turkey & 2 & 1224 & 28 & $2.00(0.80-4.80)$ & 1.90 & 47.41 & $p=0.168$ \\
\hline Spain & 1 & 562 & 17 & $3.00(1.90-4.80)$ & - & - & - \\
\hline Switzerland & 5 & 6259 & 98 & $1.50(0.80-3.00)$ & 40.02 & 90.00 & $p<0.0001$ \\
\hline Ukraine & 1 & 767 & 13 & $1.90(1.10-3.20)$ & - & - & - \\
\hline China & 3 & 1805 & 90 & $4.10(1.90-9.0)$ & 19.63 & 89.81 & $p<0.0001$ \\
\hline Israel & 1 & 1196 & 3 & $0.30(0.10-0.80)$ & - & - & - \\
\hline Japan & 4 & 4033 & 80 & $2.00(1.00-4.20)$ & 27.61 & 89.14 & $p<0.0001$ \\
\hline Mongolia & 3 & 727 & 35 & $5.10(2.20-11.50)$ & 11.87 & 83.15 & $p=0.003$ \\
\hline Thailand & 1 & 12,184 & 1 & $0.00(0.00-0.10)$ & - & - & - \\
\hline Nigeria & 1 & 700 & 0 & $0.00(0.00-0.00)$ & - & - & - \\
\hline United States & 12 & 22,300 & 806 & $4.30(3.00-6.20)$ & 237.33 & 94.95 & $p<0.0001$ \\
\hline Canada & 1 & 248 & 4 & $1.60(0.60-4.20)$ & - & - & - \\
\hline
\end{tabular}

$I^{2}$ : inverse variance; $Q-p$ : Cochran's; CI: confidence interval; MIR: minimum infection rate. Measure of heterogeneity: the weighted sum of squared differences between individual study effects and the pooled effect across studies.

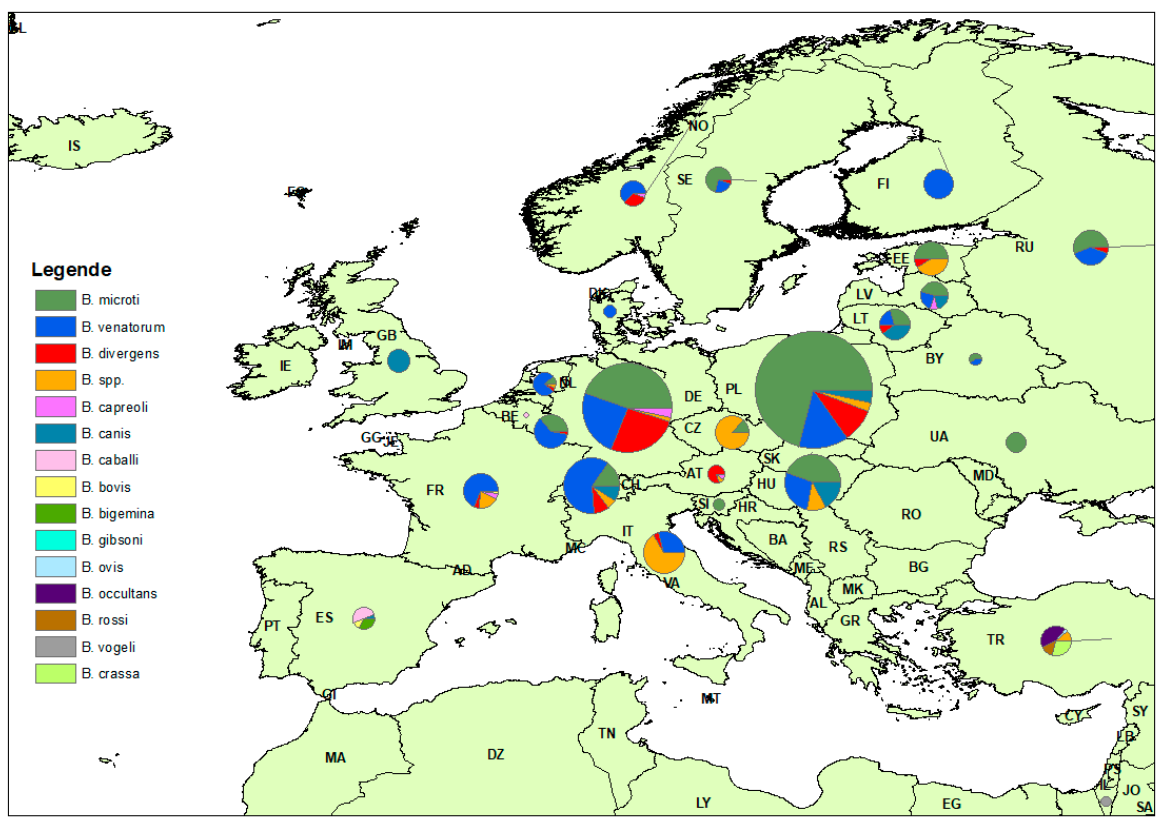

Figure 7. Distribution of Babesia species in different tick species across Europe. 


\subsection{Publication Bias}

The funnel plots and their corresponding bias coefficient (Begg and Mazumdar rank) for the estimation of the overall pooled MIR for published studies $(Z=-48.00, p=0.446)$ provides no evidence for the presence of publication bias among the eligible studies globally. For a few subgroup analyses, significant publication bias was observed for studies used for the computation of $B$. canis $(Z=-35.00, p=0.05)$, B. divergens $(Z=-72.00, p=0.01)$ and B. microti $(Z=-203.00, p=0.02)$. Additionally, mild bias was observed in studies from Asia $(Z=-32.00, p=0.014)$.

\section{Discussion}

\subsection{Babesia Species in Ticks with Medical Importance}

With the dawn of DNA-based techniques, molecular characterization has fostered the description and classification of new Babesia species. Therefore, the list of new species of Babesia continues to increase. In an attempt to synchronize the results from diverse epidemiological surveys for Babesia piroplasms in unfed host-seeking ticks comprising all live stages collected from vegetation across the globe, we undertook a systematic review and meta-analysis to estimate the pooled prevalence using random effect models.

Undoubtedly, Babesia microti was the most prevalent and widespread species of Babesia found in questing ticks in this study. DNA of B. microti has been detected in Europe, North America, and Asia with a PPE of $1.90 \%$. This finding is comparable to the individual prevalence rates reported in previous studies $[27,38,107,117]$. Higher prevalence rates above $5.00 \%$ have also been reported in several other countries like United States [114,121], Poland [79,82] and Mongolia [32].

Babesia microti, B. duncani, B. divergens and B. venatorum are all regarded as zoonotic Babesia species. Clinically, most infected individuals are asymptomatic but could register lethal evolution depending on the species of Babesia and immunocompetence of the patient [18]. It is important to note that B. microti is responsible for most cases of human babesiosis and with great impact in North America but rare in Europe and Asia [18]. In Europe, both B. divergens and B. venatorum (formerly Babesia spp. EU1) are the predominant species causing human babesiosis. Interestingly, no study reported the detection of $B$. duncani in questing ticks. However, a recent report suggests the possible role of larval forms of D. albipictus as a possible vector of B. duncani transmission [122].

With the exception of one study from Mongolia [111], studies reporting the detection of B. divergens and B. venatorum were exclusively found in Europe with a PPE below $1.00 \%$. This finding is comparable to the reports from over $70 \%$ of studies reporting the detection of this Babesia species in Europe $[17,47,48,65,106]$. The widespread presence of these species of Babesia of zoonotic importance in questing ticks has public health implications, especially in recreational parks during the period of tick activity. Therefore, humans could be exposed to pathogens with tick bites. Alternatively, blood transfusion-associated transmission has been reported in endemic areas, and it is regarded as the most common way of transmission in North America [123]. Therefore, Giemsa stained blood, serological testing or the use of PCR may significantly reduce the likelihood for transmission to occur by blood transfusion in endemic areas. Naturally, B. microti and B. divergens parasitize microtine rodents and cattle, respectively, these hosts being regarded as their reservoir [12]. On the other hand, B. venatorum is maintained naturally in wild cervids (deer), while the mule deer (Odocoileu hemionus) and possibly other species of wild ungulates in western North America may be the primary reservoir for $B$. duncani [122].

\subsection{Babesia Species in Ticks with Veterinary Importance}

Several species of Babesia are causing babesiosis in animals, including B. bovis, B. bigemina, B. occultans, B. divergens, B. ovata, B. odocoilei and B. capreoli (large ruminants and deer); B. caballi (equines); B. crassa, B. ovis, B. motasi-like and B. spp. Xinjiang (small ruminants), and B. vogeli, B. canis, B. rossi and B. gibsoni (canines). These species were observed in questing ticks across several regions. Of these species, some were observed 
to be geographically restricted (like B. ovata and B. spp. Xinjiang in Japan and China, respectively), in addition to uncharacterized Babesia species. The PPE for animal babesiosis in questing ticks ranges between $0.30 \%$ and $1.50 \%$, with the exception of $B$. spp. Xinjiang with a PPE of $6.70 \%$. These low prevalences are comparable to the infection rates reported for individual studies [24,29,41,43,47,68,108].

The PPE for B. canis was low, comparable to the prevalence reported in ticks from Slovakia [97], Russia [22] and Germany [24]. Furthermore, we observed that with the exception of $B$. canis, the agent of canine babesiosis, all other species of Babesia causing babesiosis in dogs were only reported separately, in one study each. Nonetheless, $B$. canis was reported in 14 studies from Europe. Therefore, B. canis appears to be the principal agent of canine babesiosis in Europe. In autochthonous cases where clinical canine babesiosis was reported, flagged ticks (Dermacentor reticulatus) in surrounding areas were positive to B. canis [23,41]. Additionally, in the majority of the studies (about 78\%), B. canis DNA was reported in $D$. reticulatus tick, which is a competent vector for the protozoan parasite and is frequently found in urban biotypes in Europe [21].

Babesia caballi, one of the etiological agents of equine piroplasmosis, was observed at a low infection rate. The DNA of B. caballi was observed in R. bursa [44], D. nutalli [45] and $D$. reticulatus $[41,44]$. In the latter studies, both $B$. caballi and B. canis were detected in $D$. reticulatus ticks. Interestingly, both $B$. canis and B. caballi can be maintained for several generations in $D$. reticulatus ticks [41].

The PPE for agents of small ruminant's babesiosis in questing ticks is consistent with reports from other individual studies where they occur at a very low prevalence $[43,108]$. Unlike B. motasi in Europe, B. spp. Xinjiang is known to principally infect sheep in China. From all available evidence, their presence in questing ticks is very low. Nonetheless, this Babesia spp. (B. spp. Xinjiang) has been amplified from blood samples from sheep and goats in China [28]. Earlier studies reported that Hy anatolicum anatolicum is the principal and competent vector [124]. The detection of B. spp. Xinjiang in H. longicornis and $H$. qinghaiensis, which are widespread in China, has raised several questions of their potential as vectors, but this remains speculative, and further studies will be required to verify this claim [28]. Additionally, B. crassa was detected in questing H. parva ticks in Turkey [108].

We observed seven species of bovine/cervid Babesia in host-seeking ticks. Unlike the virulent $B$. bovis and B. bigemina, B. ovata is of lower pathogenicity in cattle [29] and is one of the geographically restricted species of Babesia, similar to B. spp. Xinjiang in China. Babesia ovata is endemic in Japan and principally infects cattle [29]. H. longicornis is a known competent tick vector that can transmit the protozoan parasite transovarially [29,125], and further studies are needed to ascertain the probable role of I. ovatus that was observed to harbor this Babesia species. Additionally, B. occultans DNA was reported in Hy. marginatum, which is a known competent vector with empirical evidence from natural transovarial transmission [108], and transstadial survival [126]. Therefore, transstadial persistence of B. occultans in Hy. marginatum has been attributed to transovarial transmission of the pathogen [108], as only the adult ticks feed on the blood from cattle [127].

\subsection{Ticks as Vectors of Babesia Species}

Ixodes ricinus was the most abundant tick species in this study. This is not surprising considering that majority of the studies were from Europe, where this tick is predominant and a vector of several pathogens of protozoan, viral and bacterial agents of veterinary and medical importance $[128,129]$. Reports from various studies indicate that this tick is mostly found in urban and peri-urban areas in city parks, gardens, forest patches and litter layers [129]. Forested areas and particularly mixed and deciduous forests provide a sheltered canopy, and this tick species thrives due to the microclimates provided [128,130]. Due to climate change, current evidence points to the increasing distribution of I. ricinus steadily towards higher latitudes and altitudes. This was obvious in this study as several works were found investigating the presence of Babesia pathogen in questing tick in 
Sweden [92,93] and Finland [50]. Furthermore, I. ricinus harbors diverse Babesia species, which have been reported in Western Europe [46,52,73], Eastern Europe [98,99], Central Europe [39,104], Scandinavia [70,71,92], Southern Europe [44,64] and Balkan Peninsula [100], with varying prevalence and spread across the continent.

Other species within the genus Ixodes, such as I. persulcatus, I. ovatus and I. pavlovskyi, were reported in the Northern Hemisphere precisely in Russia and parts of southern Eurasia to harbor Babesia spp. at a prevalence ranging from 0.30 to $1.60 \%$. According to [131], I. persulcatus ticks are closely related to I. pavlovskyi. For now, the vector competence of I. pavlovskyi is largely unknown. Nonetheless, I. persulcatus has been implicated as a possible competent vector for $B$. divergens [132].

Ixodes scapularis is widely distributed in the northeast, upper Midwest, mid-Atlantic and southeast states of the United States as well as in Canada [26,133] and was observed to be the major tick vector reported from North America. The PPE of Babesia spp. in this tick was low at $3.60 \%$, comparable to the prevalence reported from other individual studies [118,120]. Higher prevalence has been reported in other parts of America [113,117]. Both B. microti and B. odocoilei are Babesia spp. found to be associated with this tick species causing human and cervid (white-tailed deer) babesiosis, respectively. The vector competence for B. odocoilei is unknown, but I. scapularis has been involved [42].

Haemaphysalis longicornis was reported in five studies, all from eastern Asia, where this tick species is native and originated from. The PPE was low to moderate at $4.3 \%$. This tick species was observed to harbor B. ovata in Japan [29] and B. spp. Xinjiang in China [28]. Therefore, babesiosis in cattle and sheep, respectively, in that region is believed to be caused by B. ovata and B. spp. Xinjiang is probably transmitted by H. longicornis.

\subsection{Association between Ticks and Babesia Including Other Factors}

Ixodid tick species play a crucial role in the epidemiology of babesiosis. Reports of the detection of Babesia DNA may not necessarily denote evidence of vector competence, whether in unfed or engorged ticks [134]. In transovarial transmission, most Babesia species invade the tick ovaries and persist in the larvae. Consequently, infection is transmitted vertically. The acquisition of the parasites (Babesia species) from their respective host by either the larvae or nymphs is referred to as transstadial transmission.

Furthermore, of all tick species in this study, I. ricinus had the highest association with several Babesia species with three and six species of human and veterinary importance, respectively. This tick is a known competent vector for 3 Babesia parasites (B. divergens, B. venatorum and B. microti), causing human babesiosis [129]. Since all stages (larvae, nymph, and adult) of $I$. ricinus can transmit B. divergens and B. venatorum, the risk of infection is high after tick bites in humans during periods of peak tick activity. Detailed review on the association of I. ricinus with Babesia and other tick-borne pathogens can be obtained elsewhere $[129,134]$.

The fact that the adult ticks and, by extension, female ticks were the most predominant with the highest infection rates compared with the nymphs and larvae may have some implications in transmission. In transovarial transmission involving most Babesia species, it has been asserted that only the female ticks can acquire the infection. Immature stages are less likely to become infected due to the smaller blood volumes they ingest. Furthermore, the fewer number and size of the midgut epithelial basophilic cells of immature stages, which play a role in parasite development, are believed to be an important factor as well [134]. Furthermore, evidence of transstadial transmission has been observed for some Babesia spp., but also, not all tick stages are capable of transmitting the parasite as observed for B. bovis, where only the larvae of R. annulatus can transmit. On the other hand, only the nymphal and adult stages of $R$. annulatus can transmit B. bigemina [134]. Additionally, many Babesia spp., including B. major, B. motasi, B. rossi, B. venatorum, B. vogeli and B. divergens, can persist from larval to their adult stages (transstadial transmission) in their competent vectors without reinfection for a minimum of one generation [134]. 
Female ticks had higher infection rates compared with their male counterparts. It is well known that female ticks require blood meals to develop their ovaries and lay thousands of eggs to perpetuate their existence. In addition, as earlier mentioned, the transovarial transmission is one of the utmost successful evolutionary strategies among the Apicomplexa and specifically in Babesia sensu stricto [20]. Therefore, female ticks take larger blood meals (high volume of blood) due to prolonged feeding, which may result in higher chances of infection. Furthermore, females require a higher number of blood meals for molting before reaching the adult stage.

The use of molecular-based techniques for the diagnosis and classification of Babesia species has been widely adopted due to greater sensitivity and specificity [18]. All studies used molecular-based techniques. In the various epidemiological investigation of Babesia species in questing ticks as observed in this study, several molecular approaches, including qPCR $[49,120]$, nested-PCR $[8,28,74]$, conventional PCR $[47,57,88]$, reverse line blot hybridization [39,43] and more recently, next-generation sequencing [33] among other methods have been adopted. Despite the observation of differences in the prevalence rates between techniques, no statistical significance was noted. Similar findings were observed in a Euro-wide meta-analysis of Borrelia burgdorferi sensu lato prevalence in questing I. ricinus ticks [135]. The highest in the prevalence rate was nested-PCR, but it is difficult to conclude considering the fact that the number of studies that utilized this technique is comparatively fewer compared with the conventional PCR. The geospatial distribution indicates that extensive studies have been conducted in Germany, Poland, and United States. This observation could be connected with a research interest in those countries with a bias towards tick-borne diseases.

This systematic review has spawned data on the prevalence of Babesia species in questing ticks. However, some limitations were observed in our study. First, we excluded articles published in languages other than English, and hence some vital information may have been set aside. Second, our study focused only on questing ticks; therefore, areas without reported Babesia pathogen may still have the pathogen. Third, due to the use of different DNA-based techniques with varying sensitivity, some Babesia species with low detection sensitivity might have been missed. Fourth, the global prevalence was obtained from studies from four continents. Therefore, the global pooled prevalence of Babesia spp. may vary from the actual estimate, but we believe that the apparent prevalence in this study is close to normal. Fifth, the heterogeneity observed could be due to sampling error, sample size, or variation of endemicity and study design. Despite the limitations highlighted above, this study used a large number of eligible studies $(n=104)$ and ticks screened $(137,364)$ from a global perspective to clearly provide a comprehensive insight and meta-analysis on the distribution of Babesia species in different questing ticks across four continents from published literature. Our results clearly indicate that these ticks harbor potentially disease-causing Babesia parasites of human and veterinary importance.

\section{Material and Methods}

\subsection{Search Strategy}

We followed the protocol as outlined by the preferred reporting items for systematic reviews and meta-analyses (PRISMA) in carrying out this systematic review and metaanalysis [136]. We searched for citations with no time restrictions through to 10 July 2020 solely in English databases of Science Direct, Springer Link, PubMed, and Google Scholar. Key operators used in the systematic search were "Babesia", "questing ticks", and "tickborne pathogens". Key terms used in the search were used individually or in combination with "AND" and/or "OR" operators. Duplicates were removed, and relevant titles and abstracts were scanned, and those articles in line with the aim of the study were downloaded.

\subsection{Inclusion and Exclusion Criteria}

Selected relevant articles, after the review of titles and abstract, were downloaded for further screening of the full text for eligibility. Included articles for the study must 
fulfill the following seven criteria, namely (i) the collected ticks must be questing ticks from vegetation, (ii) the total number of ticks screened was stated, (iii) the country of the study was known, (iv) the study screened for the presence of Babesia in questing ticks, and the number of positives/negatives was stated (v) the molecular diagnostic method employed in the study was stated (vi) for a tick species to be included in the result, at least one Babesia spp. DNA must have been amplified for that species (vii) no limit to the minimum sample size of screened ticks, but for statistical reasons, it was set at less than 40 samples. Where the exact number of the respective live stages were not clearly stated, the total number of screened ticks collected for that study was used only in the computation of the overall prevalence. Studies were excluded if (i) the exact number of positive Babesia isolates were not clearly stated, (ii) separation of the number of positive isolates of Babesia from questing ticks and other vertebrate host/feeding ticks was missing, (iii) incomplete information on tick collections (iv) lack of delineation of the results of positive Babesia species from other piroplasms (v) no information on the number of tick DNA samples used for PCR screening (vi) study with sample size below 40 .

\subsection{Data Cleaning}

In most of the studies, the developmental stages (larva and nymphs) were pooled before pathogen detection. Therefore, we calculated the minimum infection rates (MIR) (based on the assumption of a single positive tick per pool) for all included studies to avoid overestimation of a prevalence. Consequently, the prevalence throughout reflects the MIR in ticks. With regard to the years of sampling, where sampling was undertaken over two or more years, and the results were presented separately for each year, we divided the entries accordingly. Similarly, where entries involved different tick species and countries but published on the same articles, the data were separated meticulously. For the calculation of the overall prevalence, we used data from all eligible studies incorporating the total number of ticks screened irrespective of the live stages. Overall, only tick species that showed at least one positivity to Babesia spp. were presented in Table 2. Therefore, tick species reported without any single cumulative positivity to Babesia spp. were not included in the results. Furthermore, the number of positive Babesia spp. isolates that were confirmed by good quality sequences as reported in the articles were used for the subgroup analysis (Babesia species).

\subsection{Data Extraction}

All studies meeting the inclusion criteria were cataloged, and data were extracted using a charting form developed by the research team. Data extracted from all the eligible studies included all the variables as contained in the inclusion criteria, such as the name of the authors, year of sampling, geographical location, the total number of ticks screened, the molecular diagnostic technique used, the life stages of the ticks, tick species, sex of the ticks, species of Babesia detected as well as the number of positive/negative Babesia isolates. The MIR was calculated according to the various subgroups.

\subsection{Quality Assessment of Included Studies}

The quality assessment of each article included in the study was undertaken using the Joanna Briggs Institute (JBI) critical appraisal instrument for studies with prevalence data [137]. This JBI instrument consists of nine questions, of which details are available (Supplementary Table S1). Each answer to the individual question was assigned a score of 0 or 1 for no or yes answers. When the question was not applicable to the study, not applicable (NA) was used. Results of Babesia species distribution were summarized on a country level and exported as a CSV file into ArcGis Desktop (Esri, version 10.5.1, Redlands, CA, USA). Data were visualized in pie charts per country. 


\subsection{Statistical Analysis}

All statistical analyses were carried out using Comprehensive Meta-analysis (CMA) Version 3.0 by Biostat (Englewood, NJ, USA) unless otherwise stated. The weighted pooled minimum infection rate (MIR) and $95 \%$ confidence interval (CI) were computed. For each individual study, we recalculated the MIR (prevalence) by summing the total number of samples and positive cases irrespective of the number of tick species reported for that study. When the pooled analysis was performed, each logit event estimate undergoes a transformation within the CMA software into proportions with its corresponding 95\% CI. We calculated the overall MIR as a percentage. Forest plots were used to visualize the data generated. Cochran's heterogeneity $(Q)$ among the included studies, as well as the percentage inverse variation $\left(\mathrm{I}^{2}\right)$, was calculated using the Cochrane $Q$ test. If $\mathrm{I}^{2}$ was $\leq 25 \%$, $50 \%$ or $\geq 75 \%$, then heterogeneity was described as low, moderate, or high (substantial), respectively [138]. If there was only a single study for a particular category, the positive rate was computed without heterogeneity $(Q)$. All pooled estimates were arrived at using a random-effects model except for sex, where we used the fixed-effect model due to the homogeneity of the data. The chi-squared test was used to test for significance for all the subgroups using GraphPad Prism, version 5.04 (GraphPad Software, Inc, La Jolla, CA, USA, www.graphpad.com). $p$ values of $<0.05$ were considered statistically significant unless otherwise stated. Funnel plots using visual inspection and the Beg and Mazumdar rank correlation test [139] were used for assessing the publication bias.

\section{Conclusions}

In this meta-analysis of pooled data on Babesia species in questing ticks from a global perspective, our findings indicate both human and animal Babesia species DNA in a variety of species of questing hard ticks with low to moderate prevalence. We reported the detection of 19 Babesia species in 23 different tick species across four continents. Adult male and female ticks had the highest infection rates compared with immature and male ticks, respectively. Ixodes ricinus was the main tick species of interest, and it is a tick species of economic importance, with B. microti being the most widely detected species of Babesia across the different regions. The information generated from this study will be helpful to the relevant stakeholders in the design and future implementation of programs aimed at controlling competent vectors against Babesia parasites.

Supplementary Materials: The following are available online at https:/ /www.mdpi.com/2076-0 817/10/2/230/s1, Table S1: JBI Critical appraisal checklist for studies reporting prevalence data; Table S2: Quality assessment scores for eligible studies.

Author Contributions: Conceptualization, T.E.O. and C.S.; methodology, T.E.O., C.R.; validation, T.E.O., C.R., S.F. and C.S.; data curation, T.E.O., C.R., S.F. and C.S.; writing- original draft preparation, T.E.O.; writing - review and editing, C.R., S.F. and C.S.; visualization T.E.O., S.F.; supervision C.S.; All authors have read and agreed to the published version of the manuscript.

Funding: This research received no external funding.

Institutional Review Board Statement: Not applicable.

Informed Consent Statement: Not applicable.

Data Availability Statement: The data presented in this study are available in the current article and the supplementary material.

Acknowledgments: We thank Franz J. Conraths and Christoph Staubach (Friedrich-Loeffler-Institut, Greifswald-Insel Riems, Germany) for providing the ArcGIS software licenses and their useful comments on the manuscript.

Conflicts of Interest: The authors declare no conflict of interest. 


\section{References}

1. Schnittger, L.; Rodriguez, A.E.; Florin-Christensen, M.; Morrison, D.A. Babesia: A world emerging. Infect. Genet. Evol. 2012, 12, 1788-1809. [CrossRef]

2. Blaschitz, M.; Narodoslavsky-Gfoller, M.; Kanzler, M.; Stanek, G.; Walochnik, J. Babesia species occurring in Austrian Ixodes ricinus ticks. Appl. Environ. Microbiol. 2008, 74, 4841-4846. [CrossRef] [PubMed]

3. Uilenberg, G. Babesia-a historical overview. Vet. Parasitol. 2006, 138, 3-10. [CrossRef] [PubMed]

4. Homer, M.J.; Aguilar-Delfin, I.; Telford, S.R., 3rd; Krause, P.J.; Persing, D.H. Babesiosis. Clin. Microbiol. Rev. 2000, 13, 451-469. [CrossRef] [PubMed]

5. Babes, V. L'etiologie d'une enzootie des moutons, denommee Carceag en Roumanie. (The etiology of an enzootic disease of sheep, called Carceag, in Romania). C. R. Hebd. Acad. Sci. 1892, 115, 359-361.

6. Smith, T.; Kilbourne, E.L. Investigation into the Nature Causation and Prevention of Southern Cattle Fever; US Department of Agriculture, Bureau of Animal Industry: Washington, DC, USA, 1893; Volume 1, pp. 1-311.

7. Starcovici, C. Bemerkungen über den durch Babes entdeckten Blutparasiten und die durch denselben hervorgebrachten Krankheiten, die seuchenhafte Hämoglobinurie des Rindes (Babes), des Texasfieber (Th. Smith) und der Carceag der Schafe (Babes). Zbl. Bakt. I. Abt. 1893, 14, 11-18.

8. Li, L.H.; Wang, J.Z.; Zhu, D.; Li, X.S.; Lu, Y.; Yin, S.Q.; Li, S.G.; Zhang, Y.; Zhou, X.N. Detection of novel piroplasmid species and Babesia microti and Theileria orientalis genotypes in hard ticks from Tengchong County, Southwest China. Parasitol. Res. 2020, 119, 1259-1269. [CrossRef]

9. Skrabalo, Z.; Deanovic, Z. Piroplasmosis in man; report of a case. Doc. Med. Geogr. Trop. 1957, 9, 11-16. [PubMed]

10. Hunfeld, K.P.; Hildebrandt, A.; Gray, J.S. Babesiosis: Recent insights into an ancient disease. Int. J. Parasitol. 2008, 38, 1219-1237. [CrossRef] [PubMed]

11. Moritz, E.D.; Winton, C.S.; Tonnetti, L.; Townsend, R.L.; Berardi, V.P.; Hewins, M.E.; Weeks, K.E.; Dodd, R.Y.; Stramer, S.L. Screening for Babesia microti in the U.S. Blood Supply. N. Engl. J. Med. 2016, 375, 2236-2245. [CrossRef]

12. Gray, J.; Zintl, A.; Hildebrandt, A.; Hunfeld, K.P.; Weiss, L. Zoonotic babesiosis: Overview of the disease and novel aspects of pathogen identity. Ticks Tick Borne Dis. 2010, 1, 3-10. [CrossRef] [PubMed]

13. Guglielmone, A.A.; Robbins, R.G.; Apanaskevich, D.A.; Petney, T.N.; Estrada-Peña, A.; Horak, I. The Hard Ticks of the World (Acari, Ixodida, Ixodidae); Springer: New York, NY, USA, 2014; pp. 978-994.

14. Gherman, C.M.; Mihalca, A.D.; Dumitrache, M.O.; Gyorke, A.; Oroian, I.; Sandor, M.; Cozma, V. CO2 flagging-An improved method for the collection of questing ticks. Parasit. Vectors 2012, 5, 125. [CrossRef] [PubMed]

15. Petney, T.N.; Robbins, R.G.; Guglielmone, A.A.; Apanaskevich, D.A.; Estrada-Pena, A.; Horak, I.G.; Shao, R. A Look at the World of Ticks. In Progress in Parasitology; Springer: Berlin/Heidelberg, Germany, 2011; pp. 283-296.

16. Leonovich, S.A. Ontogenesis of the questing behavior of hard ticks (Ixodidae). Entomol. Rev. 2015, 95, 795-804. [CrossRef]

17. Silaghi, C.; Woll, D.; Hamel, D.; Pfister, K.; Mahling, M.; Pfeffer, M. Babesia spp. and Anaplasma phagocytophilum in questing ticks, ticks parasitizing rodents and the parasitized rodents-analyzing the host-pathogen-vector interface in a metropolitan area. Parasit Vectors 2012, 5, 191. [CrossRef] [PubMed]

18. Yabsley, M.J.; Shock, B.C. Natural history of Zoonotic Babesia: Role of wildlife reservoirs. Int. J. Parasitol. Parasites Wildl. 2013, 2, 18-31. [CrossRef] [PubMed]

19. Gray, J.S.; Weiss, L.M. Babesia microti. In Emerging Protozoan Pathogens; Khan, N., Ed.; Taylor and Francis: Abingdon, UK, 2008; pp. 303-349.

20. Jalovecka, M.; Sojka, D.; Ascencio, M.; Schnittger, L. Babesia Life Cycle-When Phylogeny Meets Biology. Trends Parasitol. 2019, 35, 356-368. [CrossRef]

21. Hornok, S.; Kartali, K.; Takacs, N.; Hofmann-Lehmann, R. Uneven seasonal distribution of Babesia canis and its two 18S rDNA genotypes in questing Dermacentor reticulatus ticks in urban habitats. Ticks Tick Borne Dis. 2016, 7, 694-697. [CrossRef] [PubMed]

22. Rar, V.A.; Fomenko, N.V.; Dobrotvorsky, A.K.; Livanova, N.N.; Rudakova, S.A.; Fedorov, E.G.; Astanin, V.B.; Morozova, O.V. Tickborne pathogen detection, Western Siberia, Russia. Emerg. Infect. Dis. 2005, 11, 1708-1715. [CrossRef]

23. Schaarschmidt, D.; Gilli, U.; Gottstein, B.; Marreros, N.; Kuhnert, P.; Daeppen, J.A.; Rosenberg, G.; Hirt, D.; Frey, C.F. Questing Dermacentor reticulatus harbouring Babesia canis DNA associated with outbreaks of canine babesiosis in the Swiss Midlands. Ticks Tick Borne Dis. 2013, 4, 334-340. [CrossRef]

24. Silaghi, C.; Weis, L.; Pfister, K. Dermacentor reticulatus and Babesia canis in Bavaria (Germany)-A Georeferenced Field Study with Digital Habitat Characterization. Pathogens 2020, 9, 541. [CrossRef]

25. Sprong, H.; Fonville, M.; Docters van Leeuwen, A.; Devillers, E.; Ibanez-Justicia, A.; Stroo, A.; Hansford, K.; Cull, B.; Medlock, J.; Heyman, P.; et al. Detection of pathogens in Dermacentor reticulatus in northwestern Europe: Evaluation of a high-throughput array. Heliyon 2019, 5, e01270. [CrossRef]

26. Milnes, E.L.; Thornton, G.; Leveille, A.N.; Delnatte, P.; Barta, J.R.; Smith, D.A.; Nemeth, N. Babesia odocoilei and zoonotic pathogens identified from Ixodes scapularis ticks in southern Ontario, Canada. Ticks Tick Borne Dis. 2019, 10, 670-676. [CrossRef] [PubMed]

27. Prusinski, M.A.; Kokas, J.E.; Hukey, K.T.; Kogut, S.J.; Lee, J.; Backenson, P.B. Prevalence of Borrelia burgdorferi (Spirochaetales: Spirochaetaceae), Anaplasma phagocytophilum (Rickettsiales: Anaplasmataceae), and Babesia microti (Piroplasmida: Babesiidae) in Ixodes scapularis (Acari: Ixodidae) collected from recreational lands in the Hudson Valley Region, New York State. J. Med. Entomol. 2014, 51, 226-236. [PubMed] 
28. Niu, Q.; Liu, Z.; Yang, J.; Gao, S.; Pan, Y.; Guan, G.; Luo, J.; Yin, H. Genetic characterization and molecular survey of Babesia sp. Xinjiang infection in small ruminants and ixodid ticks in China. Infect. Genet. Evol. 2017, 49, 330-335. [CrossRef] [PubMed]

29. Sivakumar, T.; Tattiyapong, M.; Okubo, K.; Suganuma, K.; Hayashida, K.; Igarashi, I.; Zakimi, S.; Matsumoto, K.; Inokuma, H.; Yokoyama, N. PCR detection of Babesia ovata from questing ticks in Japan. Ticks Tick Borne Dis. 2014, 5, 305-310. [CrossRef] [PubMed]

30. Zamoto-Niikura, A.; Morikawa, S.; Hanaki, K.I.; Holman, P.J.; Ishihara, C. Ixodes persulcatus Ticks as Vectors for the Babesia microti U.S. Lineage in Japan. Appl. Environ. Microbiol. 2016, 82, 6624-6632. [CrossRef]

31. Rar, V.; Livanova, N.; Tkachev, S.; Kaverina, G.; Tikunov, A.; Sabitova, Y.; Igolkina, Y.; Panov, V.; Livanov, S.; Fomenko, N.; et al. Detection and genetic characterization of a wide range of infectious agents in Ixodes pavlovskyi ticks in Western Siberia, Russia. Parasit. Vectors 2017, 10, 258. [CrossRef] [PubMed]

32. Tuvshintulga, B.; Sivakumar, T.; Battsetseg, B.; Narantsatsaral, S.O.; Enkhtaivan, B.; Battur, B.; Hayashida, K.; Okubo, K.; Ishizaki, T.; Inoue, N.; et al. The PCR detection and phylogenetic characterization of Babesia microti in questing ticks in Mongolia. Parasitol. Int. 2015, 64, 527-532. [CrossRef] [PubMed]

33. Brinkmann, A.; Hekimoglu, O.; Dincer, E.; Hagedorn, P.; Nitsche, A.; Ergunay, K. A cross-sectional screening by nextgeneration sequencing reveals Rickettsia, Coxiella, Francisella, Borrelia, Babesia, Theileria and Hemolivia species in ticks from Anatolia. Parasit. Vectors 2019, 12, 26. [CrossRef]

34. Reye, A.L.; Arinola, O.G.; Hubschen, J.M.; Muller, C.P. Pathogen prevalence in ticks collected from the vegetation and livestock in Nigeria. Appl. Environ. Microbiol. 2012, 78, 2562-2568. [CrossRef] [PubMed]

35. Aliota, M.T.; Dupuis, A.P., 2nd; Wilczek, M.P.; Peters, R.J.; Ostfeld, R.S.; Kramer, L.D. The prevalence of zoonotic tick-borne pathogens in Ixodes scapularis collected in the Hudson Valley, New York State. Vector Borne Zoonotic Dis. 2014, 14, 245-250. [CrossRef] [PubMed]

36. Franke, J.; Fritzsch, J.; Tomaso, H.; Straube, E.; Dorn, W.; Hildebrandt, A. Coexistence of pathogens in host-seeking and feeding ticks within a single natural habitat in Central Germany. Appl. Environ. Microbiol. 2010, 76, 6829-6836. [CrossRef] [PubMed]

37. Zamoto-Niikura, A.; Tsuji, M.; Qiang, W.; Nakao, M.; Hirata, H.; Ishihara, C. Detection of two zoonotic Babesia microti lineages, the Hobetsu and U.S. lineages, in two sympatric tick species, Ixodes ovatus and Ixodes persulcatus, respectively, in Japan. Appl. Environ. Microbiol. 2012, 78, 3424-3430. [CrossRef] [PubMed]

38. Overzier, E.; Pfister, K.; Herb, I.; Mahling, M.; Bock, G., Jr.; Silaghi, C. Detection of tick-borne pathogens in roe deer (Capreolus capreolus), in questing ticks (Ixodes ricinus), and in ticks infesting roe deer in southern Germany. Ticks Tick Borne Dis. 2013, 4, 320-328. [CrossRef] [PubMed]

39. Lommano, E.; Bertaiola, L.; Dupasquier, C.; Gern, L. Infections and coinfections of questing Ixodes ricinus ticks by emerging zoonotic pathogens in Western Switzerland. Appl. Environ. Microbiol. 2012, 78, 4606-4612. [CrossRef]

40. Reis, C.; Cote, M.; Paul, R.E.; Bonnet, S. Questing ticks in suburban forest are infected by at least six tick-borne pathogens. Vector Borne Zoonotic Dis. 2011, 11, 907-916. [CrossRef] [PubMed]

41. Jongejan, F.; Ringenier, M.; Putting, M.; Berger, L.; Burgers, S.; Kortekaas, R.; Lenssen, J.; van Roessel, M.; Wijnveld, M.; Madder, M. Novel foci of Dermacentor reticulatus ticks infected with Babesia canis and Babesia caballi in the Netherlands and in Belgium. Parasit. Vectors 2015, 8, 232. [CrossRef]

42. Steiner, F.E.; Pinger, R.R.; Vann, C.N.; Abley, M.J.; Sullivan, B.; Grindle, N.; Clay, K.; Fuqua, C. Detection of Anaplasma phagocytophilum and Babesia odocoilei DNA in Ixodes scapularis (Acari: Ixodidae) collected in Indiana. J. Med. Entomol. 2006, 43, 437-442. [CrossRef] [PubMed]

43. Omar Abdallah, M.; Niu, Q.; Yu, P.; Guan, G.; Yang, J.; Chen, Z.; Liu, G.; Wei, Y.; Luo, J.; Yin, H. Identification of piroplasm infection in questing ticks by RLB: A broad range extension of tick-borne piroplasm in China? Parasitol. Res. 2016, 115, 2035-2044. [CrossRef]

44. Garcia-Sanmartin, J.; Barandika, J.F.; Juste, R.A.; Garcia-Perez, A.L.; Hurtado, A. Distribution and molecular detection of Theileria and Babesia in questing ticks from northern Spain. Med. Vet. Entomol. 2008, 22, 318-325. [CrossRef]

45. Battsetseg, B.; Xuan, X.N.; Ikadai, H.; Bautista, J.L.R.; Byambaa, B.; Boldbaatar, D.; Battur, B.; Battsetseg, G.; Batsukh, Z.; Igarashi, I.; et al. Detection of Babesia caballi and Babesia equi in Dermacentor nuttalli adult ticks. Int. J. Parasitol. 2001, 31, 384-386. [CrossRef]

46. Overzier, E.; Pfister, K.; Thiel, C.; Herb, I.; Mahling, M.; Silaghi, C. Diversity of Babesia and Rickettsia species in questing Ixodes ricinus: A longitudinal study in urban, pasture, and natural habitats. Vector Borne Zoonotic Dis. 2013, 13, 559-564. [CrossRef] [PubMed]

47. Schorn, S.; Pfister, K.; Reulen, H.; Mahling, M.; Silaghi, C. Occurrence of Babesia spp., Rickettsia spp. and Bartonella spp. in Ixodes ricinus in Bavarian public parks, Germany. Parasit. Vectors 2011, 4, 135. [CrossRef] [PubMed]

48. Reye, A.L.; Stegniy, V.; Mishaeva, N.P.; Velhin, S.; Hubschen, J.M.; Ignatyev, G.; Muller, C.P. Prevalence of tick-borne pathogens in Ixodes ricinus and Dermacentor reticulatus ticks from different geographical locations in Belarus. PLoS ONE 2013, 8, e54476.

49. Klitgaard, K.; Kjaer, L.J.; Isbrand, A.; Hansen, M.F.; Bodker, R. Multiple infections in questing nymphs and adult female Ixodes ricinus ticks collected in a recreational forest in Denmark. Ticks Tick Borne Dis. 2019, 10, 1060-1065. [CrossRef]

50. Sormunen, J.J.; Andersson, T.; Aspi, J.; Back, J.; Cederberg, T.; Haavisto, N.; Halonen, H.; Hanninen, J.; Inkinen, J.; Kulha, N.; et al. Monitoring of ticks and tick-borne pathogens through a nationwide research station network in Finland. Ticks Tick Borne Dis. 2020, 11, 101449. [CrossRef] [PubMed] 
51. Sormunen, J.J.; Klemola, T.; Hanninen, J.; Makela, S.; Vuorinen, I.; Penttinen, R.; Saaksjarvi, I.E.; Vesterinen, E.J. The importance of study duration and spatial scale in pathogen detection-evidence from a tick-infested island. Emerg. Microbes Infect. 2018, 7, 189. [CrossRef]

52. Bonnet, S.; de la Fuente, J.; Nicollet, P.; Liu, X.; Madani, N.; Blanchard, B.; Maingourd, C.; Alongi, A.; Torina, A.; Fernandez de Mera, I.G.; et al. Prevalence of tick-borne pathogens in adult Dermacentor spp. ticks from nine collection sites in France. Vector Borne Zoonotic Dis. 2013, 13, 226-236. [CrossRef]

53. Cotte, V.; Bonnet, S.; Cote, M.; Vayssier-Taussat, M. Prevalence of five pathogenic agents in questing Ixodes ricinus ticks from western France. Vector Borne Zoonotic Dis. 2010, 10, 723-730. [CrossRef]

54. Halos, L.; Jamal, T.; Maillard, R.; Beugnet, F.; Le Menach, A.; Boulouis, H.J.; Vayssier-Taussat, M. Evidence of Bartonella sp. in questing adult and nymphal Ixodes ricinus ticks from France and co-infection with Borrelia burgdorferi sensu lato and Babesia sp. Vet. Res. 2005, 36, 79-87. [CrossRef]

55. Jouglin, M.; Perez, G.; Butet, A.; Malandrin, L.; Bastian, S. Low prevalence of zoonotic Babesia in small mammals and Ixodes ricinus in Brittany, France. Vet. Parasitol. 2017, 238, 58-60. [CrossRef]

56. Lejal, E.; Moutailler, S.; Simo, L.; Vayssier-Taussat, M.; Pollet, T. Tick-borne pathogen detection in midgut and salivary glands of adult Ixodes ricinus. Parasit. Vectors 2019, 12, 152. [CrossRef]

57. Eshoo, M.W.; Crowder, C.D.; Carolan, H.E.; Rounds, M.A.; Ecker, D.J.; Haag, H.; Mothes, B.; Nolte, O. Broad-range survey of tick-borne pathogens in Southern Germany reveals a high prevalence of Babesia microti and a diversity of other tick-borne pathogens. Vector Borne Zoonotic Dis. 2014, 14, 584-591. [CrossRef]

58. Franke, J.; Hildebrandt, A.; Meier, F.; Straube, E.; Dorn, W. Prevalence of Lyme disease agents and several emerging pathogens in questing ticks from the German Baltic coast. J. Med. Entomol. 2011, 48, 441-444. [CrossRef]

59. Hartelt, K.; Oehme, R.; Frank, H.; Brockmann, S.O.; Hassler, D.; Kimmig, P. Pathogens and symbionts in ticks: Prevalence of Anaplasma phagocytophilum (Ehrlichia sp.), Wolbachia sp., Rickettsia sp., and Babesia sp in Southern Germany. Int. J. Med. Microbiol. 2004, 293, 86-92. [CrossRef]

60. Hildebrandt, A.; Pauliks, K.; Sachse, S.; Straube, E. Coexistence of Borrelia spp. and Babesia spp. in Ixodes ricinus ticks in Middle Germany. Vector Borne Zoonotic Dis. 2010, 10, 831-837. [CrossRef] [PubMed]

61. Hildebrandt, A.; Fritzsch, J.; Franke, J.; Sachse, S.; Dorn, W.; Straube, E. Co-circulation of emerging tick-borne pathogens in Middle Germany. Vector Borne Zoonotic Dis. 2011, 11, 533-537. [CrossRef]

62. Kohn, M.; Krucken, J.; McKay-Demeler, J.; Pachnicke, S.; Krieger, K.; von Samson-Himmelstjerna, G. Dermacentor reticulatus in Berlin/Brandenburg (Germany): Activity patterns and associated pathogens. Ticks Tick Borne Dis. 2019, 10, 191-206. [CrossRef]

63. Egyed, L.; Elo, P.; Sreter-Lancz, Z.; Szell, Z.; Balogh, Z.; Sreter, T. Seasonal activity and tick-borne pathogen infection rates of Ixodes ricinus ticks in Hungary. Ticks Tick Borne Dis. 2012, 3, 90-94. [CrossRef] [PubMed]

64. Capelli, G.; Ravagnan, S.; Montarsi, F.; Ciocchetta, S.; Cazzin, S.; Porcellato, E.; Babiker, A.M.; Cassini, R.; Salviato, A.; Cattoli, G.; et al. Occurrence and identification of risk areas of Ixodes ricinus-borne pathogens: A cost-effectiveness analysis in north-eastern Italy. Parasit. Vector 2012, 5, 61. [CrossRef] [PubMed]

65. Cassini, R.; Bonoli, C.; Montarsi, F.; Tessarin, C.; Marcer, F.; Galuppi, R. Detection of Babesia EU1 in Ixodes ricinus ticks in northern Italy. Vet. Parasitol. 2010, 171, 151-154. [CrossRef] [PubMed]

66. Floris, R.; Cecco, P.; Mignozzi, K.; Boemo, B.; Cinco, M. First detection of Babesia EU1 and Babesia divergens-like in Ixodes ricinus ticks in north-eastern Italy. Parassitologia 2009, 51, 23-28.

67. Piccolin, G.; Benedetti, G.; Doglioni, C.; Lorenzato, C.; Mancuso, S.; Papa, N.; Pttton, L.; Ramon, M.C.; Zasio, C.; Bertiato, G. A study of the presence of Borrelia burgdorferi, Anaplasma (previously Ehrlichia) phagocytophilum, Rickettsia, and Babesia in Ixodes ricinus collected within the territory of Belluno, Italy. Vector-Borne Zoonot. 2006, 6, 24-31. [CrossRef] [PubMed]

68. Capligina, V.; Berzina, I.; Bormane, A.; Salmane, I.; Vilks, K.; Kazarina, A.; Bandere, D.; Baumanis, V.; Ranka, R. Prevalence and phylogenetic analysis of Babesia spp. in Ixodes ricinus and Ixodes persulcatus ticks in Latvia. Exp. Appl. Acarol. 2016, 68, 325-336. [CrossRef]

69. Radzijevskaja, J.; Mardosaite-Busaitiene, D.; Aleksandraviciene, A.; Paulauskas, A. Investigation of Babesia spp. in sympatric populations of Dermacentor reticulatus and Ixodes ricinus ticks in Lithuania and Latvia. Ticks Tick-Borne Dis. 2018, 9, 270-274. [CrossRef]

70. Oines, O.; Radzijevskaja, J.; Paulauskas, A.; Rosef, O. Prevalence and diversity of Babesia spp. in questing Ixodes ricinus ticks from Norway. Parasit. Vectors 2012, 5, 156. [CrossRef]

71. Radzijevskaja, J.; Paulauskas, A.; Rosef, O. Prevalence of Anaplasma phagocytophilum and Babesia divergens in Ixodes ricinus ticks from Lithuania and Norway. Int. J. Med. Microbiol. 2008, 298, 218-221. [CrossRef]

72. Žygutienè, M.; Alekseev, A.; Dubinina, H.; Kazlauskienè, R. Evidence for a risk of tick-borne infection in the city parks of Vilnius, Lithuania. EKOLOGIJA 2008, 54, 40-43. [CrossRef]

73. Wielinga, P.R.; Fonville, M.; Sprong, H.; Gaasenbeek, C.; Borgsteede, F.; van der Giessen, J.W.B. Persistent Detection of Babesia EU1 and Babesia microti in Ixodes ricinus in The Netherlands During a 5-Year Surveillance: 2003-2007. Vector-Borne Zoonot. 2009, 9 , 119-121. [CrossRef]

74. Asman, M.; Solarz, K.; Cuber, P.; Gasior, T.; Szilman, P.; Szilman, E.; Tondas, E.; Matzullok, A.; Kusion, N.; Florek, K. Detection of protozoans Babesia microti and Toxoplasma gondii and their co-existence in ticks (Acari: Ixodida) collected in Tarnogorski district (Upper Silesia, Poland). Ann. Agric. Environ. Med. 2015, 22, 80-83. [CrossRef] [PubMed] 
75. Cieniuch, S.; Stanczak, J.; Ruczaj, A. The First Detection of Babesia EU1 and Babesia canis canis in Ixodes ricinus Ticks (Acari, Ixodidae) Collected in Urban and Rural Areas in Northern Poland. Pol. J. Microbiol. 2009, 58, 231-236.

76. Karbowiak, G.; Vichova, B.; Slivinska, K.; Werszko, J.; Didyk, J.; Pet'ko, B.; Stanko, M.; Akimov, I. The infection of questing Dermacentor reticulatus ticks with Babesia canis and Anaplasma phagocytophilum in the Chernobyl exclusion zone. Vet. Parasitol. 2014, 204, 372-375. [CrossRef] [PubMed]

77. Pieniazek, N.; Sawczuk, M.; Skotarczak, B. Molecular identification of Babesia parasites isolated from Ixodes ricinus ticks collected in northwestern Poland. J. Parasitol. 2006, 92, 32-35. [CrossRef] [PubMed]

78. Sinski, E.; Bajer, A.; Welc, R.; Pawelczyk, A.; Ogrzewalska, M.; Behnke, J.M. Babesia microti: Prevalence in wild rodents and Ixodes ricinus ticks from the Mazury Lakes District of north-eastern Poland. Int. J. Med. Microbiol. 2006, 296, 137-143. [CrossRef] [PubMed]

79. Skotarczak, B.; Wodecka, B.; Cichocka, A. Coexistence DNA of Borrelia burgdorferi sensu lato and Babesia microti in Ixodes ricinus ticks from north-western Poland. Ann. Agric. Environ. Med. 2002, 9, 25-28.

80. Stanczak, J.; Cieniuch, S.; Lass, A.; Biernat, B.; Racewicz, M. Detection and quantification of Anaplasma phagocytophilum and Babesia spp. in Ixodes ricinus ticks from urban and rural environment, northern Poland, by real-time polymerase chain reaction. Exp. Appl. Acarol. 2015, 66, 63-81. [CrossRef] [PubMed]

81. Welc-Faleciak, R.; Bajer, A.; Paziewska-Harris, A.; Baumann-Popczyk, A.; Sinski, E. Diversity of Babesia in Ixodes ricinus ticks in Poland. Adv. Med. Sci. Pol. 2012, 57, 364-369. [CrossRef] [PubMed]

82. Wojcik-Fatla, A.; Bartosik, K.; Buczek, A.; Dutkiewicz, J. Babesia microti in adult Dermacentor reticulatus ticks from Eastern Poland. Vector-Borne Zoonot. 2012, 12, 841-843. [CrossRef] [PubMed]

83. Wojcik-Fatla, A.; Zajac, V.; Sawczyn, A.; Cisak, E.; Dutkiewicz, J. Babesia spp. in questing ticks from eastern Poland: Prevalence and species diversity. Parasitol. Res. 2015, 114, 3111-3116. [CrossRef] [PubMed]

84. Zajac, V.; Wojcik-Fatla, A.; Sawczyn, A.; Cisak, E.; Sroka, J.; Kloc, A.; Zajac, Z.; Buczek, A.; Dutkiewicz, J.; Bartosik, K. Prevalence of infections and co-infections with 6 pathogens in Dermacentor reticulatus ticks collected in eastern Poland. Ann. Agric. Environ. Med. 2017, 24, 26-32. [CrossRef] [PubMed]

85. Wojcik-Fatla, A.; Szymanska, J.; Wdowiak, L.; Buczek, A.; Dutkiewicz, J. Coincidence of three pathogens (Borrelia burgdorferi sensu lato, Anaplasma phagocytophilum and Babesia microti) in Ixodes ricinus ticks in the Lublin Macroregion. Ann. Agric. Environ. Med. 2009, 16, 151-158. [PubMed]

86. Stanczak, J.; Gabre, R.M.; Kruminis-Lozowska, W.; Racewicz, M.; Kubica-Biernat, B. Ixodes ricinus as a vector of Borrelia burgdorferi sensu lato, Anaplasma phagocytophilum and Babesia microti in urban and suburban forests. Ann. Agric. Environ. Med. 2004, 11, 109-114. [PubMed]

87. Katargina, O.; Geller, J.; Vasilenko, V.; Kuznetsova, T.; Jarvekulg, L.; Vene, S.; Lundkvist, A.; Golovljova, I. Detection and characterization of Babesia species in Ixodes ticks in Estonia. Vector Borne Zoonotic Dis. 2011, 11, 923-928. [CrossRef]

88. Maia, C.; Ferreira, A.; Nunes, M.; Vieira, M.L.; Campino, L.; Cardoso, L. Molecular detection of bacterial and parasitic pathogens in hard ticks from Portugal. Ticks Tick Borne Dis. 2014, 5, 409-414. [CrossRef] [PubMed]

89. Santos-Silva, M.M.; Melo, P.; Santos, N.; Antunes, S.; Duarte, L.R.; Ferrolho, J.; Milhano, N.; Santos, P.T.; Domingos, A.; Santos, A.S. PCR screening of tick-borne agents in sensitive conservation areas, Southeast Portugal. Mol. Cell. Probes 2017, $31,42-45$. [CrossRef]

90. Reye, A.L.; Hubschen, J.M.; Sausy, A.; Muller, C.P. Prevalence and seasonality of tick-borne pathogens in questing Ixodes ricinus ticks from Luxembourg. Appl. Environ. Microbiol. 2010, 76, 2923-2931. [CrossRef] [PubMed]

91. Ionita, M.; Mitrea, I.L.; Pfister, K.; Hamel, D.; Silaghi, C. Molecular evidence for bacterial and protozoan pathogens in hard ticks from Romania. Vet. Parasitol. 2013, 196, 71-76. [CrossRef] [PubMed]

92. Karlsson, M.E.; Andersson, M.O. Babesia species in questing Ixodes ricinus, Sweden. Ticks Tick Borne Dis. 2016, 7, 10-12. [CrossRef] [PubMed]

93. Jaenson, T.G.T.; Wilhelmsson, P. First records of tick-borne pathogens in populations of the taiga tick Ixodes persulcatus in Sweden. Parasit. Vectors 2019, 12, 559. [CrossRef]

94. Alekseev, A.N.; Semenov, A.V.; Dubinina, H.V. Evidence of Babesia microti infection in multi-infected Ixodes persulcatus ticks in Russia. Exp. Appl. Acarol. 2003, 29, 345-353. [CrossRef] [PubMed]

95. Movila, A.; Dubinina, H.V.; Sitnicova, N.; Bespyatova, L.; Uspenskaia, I.; Efremova, G.; Toderas, I.; Alekseev, A.N. Comparison of tick-borne microorganism communities in Ixodes spp. of the Ixodes ricinus species complex at distinct geographical regions. Exp. Appl. Acarol. 2014, 63, 65-76. [CrossRef]

96. Rar, V.A.; Epikhina, T.I.; Livanova, N.N.; Panov, V.V. Genetic diversity of Babesia in Ixodes persulcatus and small mammals from North Ural and West Siberia, Russia. Parasitology 2011, 138, 175-182. [CrossRef]

97. Duh, D.; Slovak, M.; Saksida, A.; Stramsek, K.; Petrovec, M.; Avsic-Zupanc, T. Molecular detection of Babesia canis in Dermacentor reticulatus ticks collected in Slovakia. Biologia 2006, 61, 231-233. [CrossRef]

98. Hamsikova, Z.; Kazimirova, M.; Harustiakova, D.; Mahrikova, L.; Slovak, M.; Berthova, L.; Kocianova, E.; Schnittger, L. Babesia spp. in ticks and wildlife in different habitat types of Slovakia. Parasit. Vectors 2016, 9, 292. [CrossRef]

99. Svehlova, A.; Berthova, L.; Sallay, B.; Boldis, V.; Sparagano, O.A.; Spitalska, E. Sympatric occurrence of Ixodes ricinus, Dermacentor reticulatus and Haemaphysalis concinna ticks and Rickettsia and Babesia species in Slovakia. Ticks Tick Borne Dis. 2014, 5, 600-605. [CrossRef] 
100. Duh, D.; Petrovec, M.; Avsic-Zupanc, T. Diversity of Babesia infecting European sheep ticks (Ixodes ricinus). J. Clin. Microbiol. 2001, 39, 3395-3397. [CrossRef] [PubMed]

101. Rudolf, I.; Golovchenko, M.; Sikutova, S.; Rudenko, N.; Grubhoffer, L.; Hubalek, Z. Babesia microti (Piroplasmida: Babesiidae) in nymphal Ixodes ricinus (Acari: Ixodidae) in the Czech Republic. Folia. Parasitol. (Praha) 2005, 52, 274-276. [CrossRef] [PubMed]

102. Venclikova, K.; Mendel, J.; Betasova, L.; Blazejova, H.; Jedlickova, P.; Strakova, P.; Hubalek, Z.; Rudolf, I. Neglected tick-borne pathogens in the Czech Republic, 2011-2014. Ticks Tick Borne Dis. 2016, 7, 107-112. [CrossRef]

103. Cochez, C.; Lempereur, L.; Madder, M.; Claerebout, E.; Simons, L.; De Wilde, N.; Linden, A.; Saegerman, C.; Heyman, P.; Losson, B. Foci report on indigenous Dermacentor reticulatus populations in Belgium and a preliminary study of associated babesiosis pathogens. Med. Vet. Entomol. 2012, 26, 355-358. [CrossRef] [PubMed]

104. Casati, S.; Sager, H.; Gern, L.; Piffaretti, J.C. Presence of potentially pathogenic Babesia sp. for human in Ixodes ricinus in Switzerland. Ann. Agric. Environ. Med. 2006, 13, 65-70.

105. Gigandet, L.; Stauffer, E.; Douet, V.; Rais, O.; Moret, J.; Gern, L. Prevalence of three zoonotic Babesia species in Ixodes ricinus (Linne, 1758) nymphs in a suburban forest in Switzerland. Vector Borne Zoonotic Dis. 2011, 11, 363-366. [CrossRef]

106. Oechslin, C.P.; Heutschi, D.; Lenz, N.; Tischhauser, W.; Peter, O.; Rais, O.; Beuret, C.M.; Leib, S.L.; Bankoul, S.; Ackermann-Gaumann, R. Prevalence of tick-borne pathogens in questing Ixodes ricinus ticks in urban and suburban areas of Switzerland. Parasit. Vectors 2017, 10, 558. [CrossRef] [PubMed]

107. Didyk, Y.M.; Blanarova, L.; Pogrebnyak, S.; Akimov, I.; Petko, B.; Vichova, B. Emergence of tick-borne pathogens (Borrelia burgdorferi sensu lato, Anaplasma phagocytophilum, Ricketsia raoultii and Babesia microti) in the Kyiv urban parks, Ukraine. Ticks Tick Borne Dis. 2017, 8, 219-225. [CrossRef]

108. Orkun, O.; Cakmak, A.; Nalbantoglu, S.; Karaer, Z. Turkey tick news: A molecular investigation into the presence of tick-borne pathogens in host-seeking ticks in Anatolia; Initial evidence of putative vectors and pathogens, and footsteps of a secretly rising vector tick, Haemaphysalis parva. Ticks Tick Borne Dis. 2020, 11, 101373. [CrossRef]

109. Harrus, S.; Perlman-Avrahami, A.; Mumcuoglu, K.Y.; Morick, D.; Eyal, O.; Baneth, G. Molecular detection of Ehrlichia canis, Anaplasma bovis, Anaplasma platys, Candidatus Midichloria mitochondrii and Babesia canis vogeli in ticks from Israel. Clin. Microbiol. Infect. 2011, 17, 459-463. [CrossRef]

110. Masatani, T.; Hayashi, K.; Andoh, M.; Tateno, M.; Endo, Y.; Asada, M.; Kusakisako, K.; Tanaka, T.; Gokuden, M.; Hozumi, N.; et al. Detection and molecular characterization of Babesia, Theileria, and Hepatozoon species in hard ticks collected from Kagoshima, the southern region in Japan. Ticks Tick Borne Dis. 2017, 8, 581-587. [CrossRef]

111. Karnath, C.; Obiegala, A.; Speck, S.; Essbauer, S.; Derschum, H.; Scholz, H.; Kiefer, D.; Tserennorov, D.; Dashdavaa, O.; Tsogbadrakh, N.; et al. Detection of Babesia venatorum, Anaplasma phagocytophilum and Candidatus Neoehrlichia mikurensis in Ixodes persulcatus ticks from Mongolia. Ticks Tick-Borne Dis. 2016, 7, 357-360. [CrossRef]

112. Wattanamethanont, J.; Kaewthamasorn, M.; Tiawsirisup, S. Natural infection of questing ixodid ticks with protozoa and bacteria in Chonburi Province, Thailand. Ticks Tick Borne Dis. 2018, 9, 749-758. [CrossRef]

113. Adelson, M.E.; Rao, R.V.; Tilton, R.C.; Cabets, K.; Eskow, E.; Fein, L.; Occi, J.L.; Mordechai, E. Prevalence of Borrelia burgdorferi, Bartonella spp., Babesia microti, and Anaplasma phagocytophila in Ixodes scapularis ticks collected in Northern New Jersey. J. Clin. Microbiol. 2004, 42, 2799-2801. [CrossRef]

114. Edwards, M.J.; Barbalato, L.A.; Makkapati, A.; Pham, K.D.; Bugbee, L.M. Relatively low prevalence of Babesia microti and Anaplasma phagocytophilum in Ixodes scapularis ticks collected in the Lehigh Valley region of eastern Pennsylvania. Ticks Tick Borne Dis. 2015, 6, 812-819. [CrossRef] [PubMed]

115. Piesman, J.; Mather, T.N.; Telford, S.R., 3rd; Spielman, A. Concurrent Borrelia burgdorferi and Babesia microti infection in nymphal Ixodes dammini. J. Clin. Microbiol. 1986, 24, 446-447. [CrossRef]

116. Varde, S.; Beckley, J.; Schwartz, I. Prevalence of tick-borne pathogens in Ixodes scapularis in a rural New Jersey County. Emerg. Infect. Dis. 1998, 4, 97-99. [CrossRef]

117. Steiner, F.E.; Pinger, R.R.; Vann, C.N.; Grindle, N.; Civitello, D.; Clay, K.; Fuqua, C. Infection and co-infection rates of Anaplasma phagocytophilum variants, Babesia spp., Borrelia burgdorferi, and the rickettsial endosymbiont in Ixodes scapularis (Acari: Ixodidae) from sites in Indiana, Maine, Pennsylvania, and Wisconsin. J. Med. Entomol. 2008, 45, 289-297. [CrossRef] [PubMed]

118. Edwards, M.J.; Russell, J.C.; Davidson, E.N.; Yanushefski, T.J.; Fleischman, B.L.; Heist, R.O.; Leep-Lazar, J.G.; Stuppi, S.L.; Esposito, R.A.; Suppan, L.M. A 4-Yr Survey of the Range of Ticks and Tick-Borne Pathogens in the Lehigh Valley Region of Eastern Pennsylvania. J. Med. Entomol. 2019, 56, 1122-1134. [CrossRef]

119. Russart, N.M.; Dougherty, M.W.; Vaughan, J.A. Survey of ticks (Acari: Ixodidae) and tick-borne pathogens in North Dakota. J. Med. Entomol. 2014, 51, 1087-1090. [CrossRef]

120. Hutchinson, M.L.; Strohecker, M.D.; Simmons, T.W.; Kyle, A.D.; Helwig, M.W. Prevalence Rates of Borrelia burgdorferi (Spirochaetales: Spirochaetaceae), Anaplasma phagocytophilum (Rickettsiales: Anaplasmataceae), and Babesia microti (Piroplasmida: Babesiidae) in host-seeking Ixodes scapularis (Acari: Ixodidae) from Pennsylvania. J. Med. Entomol. 2015, 52, 693-698. [CrossRef] [PubMed]

121. Hersh, M.H.; Ostfeld, R.S.; McHenry, D.J.; Tibbetts, M.; Brunner, J.L.; Killilea, M.E.; LoGiudice, K.; Schmidt, K.A.; Keesing, F. Co-infection of blacklegged ticks with Babesia microti and Borrelia burgdorferi is higher than expected and acquired from small mammal hosts. PLoS ONE 2014, 9, e99348. [CrossRef] 
122. Swei, A.; O'Connor, K.E.; Couper, L.I.; Thekkiniath, J.; Conrad, P.A.; Padgett, K.A.; Burns, J.; Yoshimizu, M.H.; Gonzales, B.; Munk, B.; et al. Evidence for transmission of the zoonotic apicomplexan parasite Babesia duncani by the tick Dermacentor albipictus. Int. J. Parasitol. 2019, 49, 95-103. [CrossRef]

123. Young, C.; Chawla, A.; Berardi, V.; Padbury, J.; Skowron, G.; Krause, P.J.; Containment, B.T.I. Preventing transfusion-transmitted babesiosis: Preliminary experience of the first laboratory-based blood donor screening program. Transfusion 2012, 52, 1523-1529. [CrossRef]

124. Guan, G.; Ma, M.; Moreau, E.; Liu, J.; Lu, B.; Bai, Q.; Luo, J.; Jorgensen, W.; Chauvin, A.; Yin, H. A new ovine Babesia species transmitted by Hyalomma anatolicum anatolicum. Exp. Parasitol. 2009, 122, 261-267. [CrossRef] [PubMed]

125. Bai, Q.; Liu, G.Y.; Zhang, L.; Zhou, J.Y. Studies on the isolation and preservation of a single species of bovine haematocytozoon: The finding and isolation of Babesia ovata in China. Chin. J. Vet. Med. 1990, 16, 2-4.

126. Aktas, M. A survey of ixodid tick species and molecular identification of tick-borne pathogens. Vet. Parasitol. 2014, 200, 276-283. [CrossRef]

127. Hoogstraal, H. The epidemiology of tick-borne Crimean-Congo hemorrhagic fever in Asia, Europe, and Africa. J. Med. Entomol. 1979, 15, 307-417. [CrossRef] [PubMed]

128. Medlock, J.M.; Hansford, K.M.; Bormane, A.; Derdakova, M.; Estrada-Pena, A.; George, J.C.; Golovljova, I.; Jaenson, T.G.; Jensen, J.K.; Jensen, P.M.; et al. Driving forces for changes in geographical distribution of Ixodes ricinus ticks in Europe. Parasit. Vectors 2013, 6, 1. [CrossRef] [PubMed]

129. Rizzoli, A.; Silaghi, C.; Obiegala, A.; Rudolf, I.; Hubalek, Z.; Foldvari, G.; Plantard, O.; Vayssier-Taussat, M.; Bonnet, S.; Spitalska, E.; et al. Ixodes ricinus and its transmitted pathogens in urban and peri-urban areas in Europe: New hazards and relevance for public health. Front. Public Health 2014, 2, 251. [CrossRef] [PubMed]

130. Ribeiro, R.; Eze, J.I.; Gilbert, L.; Wint, G.R.W.; Gunn, G.; Macrae, A.; Medlock, J.M.; Auty, H. Using imperfect data in predictive mapping of vectors: A regional example of Ixodes ricinus distribution. Parasit. Vector 2019, 12, 536. [CrossRef] [PubMed]

131. Livanova, N.N.; Tikunov, A.Y.; Kurilshikov, A.M.; Livanov, S.G.; Fomenko, N.V.; Taranenko, D.E.; Kvashnina, A.E.; Tikunova, N.V. Genetic diversity of Ixodes pavlovskyi and I. persulcatus (Acari: Ixodidae) from the sympatric zone in the south of Western Siberia and Kazakhstan. Exp. Appl. Acarol. 2015, 67, 441-456. [CrossRef] [PubMed]

132. Friedhoff, K.T. Transmission of Babesia. In Babesiosis of Domestic Animals and Man; Ristic, M., Ed.; CRC Press: Boca Raton, FL, USA, 1988. [CrossRef]

133. Eisen, R.J.; Eisen, L. The Blacklegged Tick, Ixodes scapularis: An increasing public health concern. Trends Parasitol. 2018, 34, 295-309. [CrossRef]

134. Gray, J.S.; Estrada-Pena, A.; Zintl, A. Vectors of Babesiosis. Annu. Rev. Entomol. 2019, 64, 149-165. [CrossRef]

135. Strnad, M.; Honig, V.; Ruzek, D.; Grubhoffer, L.; Rego, R.O.M. Europe-Wide Meta-Analysis of Borrelia burgdorferi sensu lato prevalence in questing Ixodes ricinus Ticks. Appl. Environ. Microbiol. 2017, 83, e00609-17. [CrossRef]

136. Moher, D.; Shamseer, L.; Clarke, M.; Ghersi, D.; Liberati, A.; Petticrew, M.; Shekelle, P.; Stewart, L.A.; Group, P.-P. Preferred reporting items for systematic review and meta-analysis protocols (PRISMA-P) 2015 statement. Syst. Rev. 2015, 4, 1. [CrossRef] [PubMed]

137. Munn, Z.; Moola, S.; Lisy, K.; Riitano, D.; Tufanaru, C. Methodological guidance for systematic reviews of observational epidemiological studies reporting prevalence and cumulative incidence data. Int. J. Evid. Based Healthc. 2015, 13, 147-153. [CrossRef] [PubMed]

138. Higgins, J.P.T.; Thompson, S.G. Quantifying heterogeneity in a meta-analysis. Stat. Med. 2002, 21, 1539-1558. [CrossRef] [PubMed]

139. Begg, C.B.; Mazumdar, M. Operating characteristics of a rank correlation test for publication bias. Biometrics 1994, 50, 1088-1101. [CrossRef] [PubMed] 